\title{
ГЕОФІЗИКА
}

УДК 550.36

\section{А. НАЗАРЕВИЧ}

Карпатське відділення Інституту геофізики ім. С. І. Субботіна НАН України, 79060, м. Львів, вул. Наукова, 3б, тел. +38(032)2648563, ел. пошта nazarevych-a@cb-igph.lviv.ua

\section{ДО ПРОБЛЕМИ ПІДВИЩЕННЯ ГЛИБИННОСТІ, ЧУТЛИВОСТІ І ТОЧНОСТІ МОНТТОРИНГОВИХ ТА НАФТОГАЗОПОШУКОВИХ СВЕРДЛОВИННИХ ГЕОТЕРМІЧНИХ ДОСЛІДЖЕНЬ}

https://doi.org/10.23939/jgd2018.01.060

Мета. Метою роботи є представити напрацьовані нами важливі методико-апаратурні розробки, спрямовані на підвищення глибинності, чутливості та точності моніторингових і нафтогазопошукових свердловинних геотермічних досліджень. Методика. Методика містить аналіз низки методико-апаратурних факторів, що впливають на глибинність, чутливість і точність свердловинних геотермічних досліджень 3 використанням розробленої свердловинної апаратури з кварцовим термочастотним сенсором і відповідні методико-апаратурні розробки для підвищення цієї глибинності, чутливості і точності. Результати. Аналіз результатів проведених нами раніше свердловинних геотермічних досліджень з використанням розробленої свердловинної апаратури 3 кварцовим термочастотним сенсором показав, що разом 3 високою загальною чутливістю і точністю розробленої апаратури наявні обмеження іiі глибинності через недостатню герметичність зонда під час роботи у свердловинах на великих глибинах за чинних там високих гідростатичних тисків рідини, що заповнює свердловину. Тому першочергово вдосконалено конструкцію зонда з метою забезпечення його надійної роботи на великих глибинах. Також наявне обмеження глибинності (зокрема, допустимої довжини каротажного кабеля) свердловинних досліджень за “прямої" передачі результатів вимірювань цим кабелем через велике загасання сигналу на робочій частоті високочастотного кварцового термочутливого сенсора. Тому робочу частоту каналу передачі результатів кратно знижено через використання цифрового дільника частоти. Спостерігається також вплив на ці результати низки методикоапаратурних факторів, що погіршують їхню якість, особливо, при відстежуванні швидких змін температури у свердловині під час ії термопрофілювання (високошвидкісного термокаротажу) або режимного моніторингу. Це, зокрема, теплова інерційність свердловинного зонда. Для нейтралізації впливу цієї інерційності проведено iі дослідження і запропоновано спосіб редукції іiі впливу шляхом введення відповідних таймінгозалежних температурних поправок. Проведено термопрофілювання низки гідротермальних свердловин заходу України і отримані результати відкоректовано з урахуванням перелічених поправок. Розроблено методику виявлення і врахування метеотемпературних впливів на результати сейсмопрогностичних моніторингових досліджень за даними геотермічного моніторингу масивів порід. Ї̈і представлено на прикладі виділення на фоні сезонних термопружних деформацій малоамплітудного деформаційного провісника місцевого закарпатського землетрусу. Наукова новизна. Досягнуто підвищення чутливості i точності моніторингових та нафтогазопошукових свердловинних геотермічних досліджень 3 використанням розробленої свердловинної геотермічної апаратури з кварцовим термочастотним сенсором, шляхом, зокрема, дослідження, визначення і врахування таймінгових температурних поправок (“інтервальних зміщень”) і поправок за теплову інерційність свердловинного зонда. Детально досліджено температурні профілі ряду гідротермальних свердловин заходу України і встановлено особливості зміни в них температур з глибиною. За рахунок редукції з деформографічних даних змодельованих за результатами геотермічного моніторингу сезонних термопружних деформацій порід виділено малоамплітудний деформаційний провісник місцевого закарпатського землетрусу. Практична значущість. Досягнуто підвищення глибинності геотермічних досліджень з використанням розробленої свердловинної геотермічної апаратури за рахунок використання кратно зниженої частоти передачі вимірюваного сигналу каротажним кабелем і вдосконалення конструкції та схемотехніки свердловинного зонда.

Ключові слова: термокаротаж; свердловинний зонд; кварцовий термочастотний сенсор; теплова інерційність; температурні поправки; температурний профіль свердловини; динамічні температурні варіації, провісники землетрусів.

\section{Bcmyn}

Геотермічний метод $є$ одним з тих, які активно використовуються у нафтогазопошукових, сейсмопрогностичних та інших моніторингових дослідженнях ([Чекалюк, 1965; Чекалюк и др., 1974; Гогель, 1978; Кутас, 1978, 2005; Кутас, Гордиенко,
1971; Гордиенко и др., 2002, 2011; Осадчий та ін., 2008; Назаревич, 2011, Назаревич и др., 2014; Назаревич, Микита, 2012; Hvožd'ara et al., 1988; Kalenda et al., 2014] та ін.). Зокрема, моніторингові сейсмопрогностичні геотермічні дослідження ведемо на пунктах спостережень Карпатсь- 
кого відділення Інституту геофізики ім. C. І. Субботіна НАН України в Закарпатті - на режимних геофізичних станціях (РГС) “Берегове" i "Тросник" та геотермічному пункті "Косино" [Назаревич, 2011; Назаревич, Микита, 2010, 2012; Назаревич та ін., 2016] (рис. 1). Нижче представлено результати досліджень і випробувань розробленої свердловинної апаратури з кварцовим термочастотним сенсором і заходи, спрямовані на підвищення іiі глибинності, чутливості і точності для моніторингових та нафтогазопошукових свердловинних геотермічних досліджень.

\section{Mema}

Метою роботи є представити наші напрацьовані важливі методико-апаратурні розробки, спрямовані на підвищення глибинності, чутливості та точності моніторингових i нафтогазопошукових свердловинних геотермічних досліджень.

\section{Методика}

Методика свердловинних геотермічних досліджень враховує геолого-геофізичні характеристики глибинних теплових полів у масивах порід [Гогель, 1978; Кутас, 1978, 2005; Кутас, Гордиенко, 1971; Фролов, 1966; Чекалюк и др., 1974] i передбачає термокаротаж (термопрофілювання досліджуваної свердловини) під час нафтогазопошукових, гідротермальних та гідрогеологічних досліджень [Назаревич и др., 2014; Назаревич, Микита, 2010, 2012; Назаревич, Назаревич, 2017] або режимні спостереження на фіксованих глибинах під час моніторингових досліджень [Назаревич, Микита, 2010, 2012].

Застосовувана для геотермічних досліджень апаратура повинна володіти відповідними метрологічними (чутливість і точність (зокрема довготривала стабільність)) та експлуатаційними (глибинність, надійність) характеристиками [Назаревич, 2011].

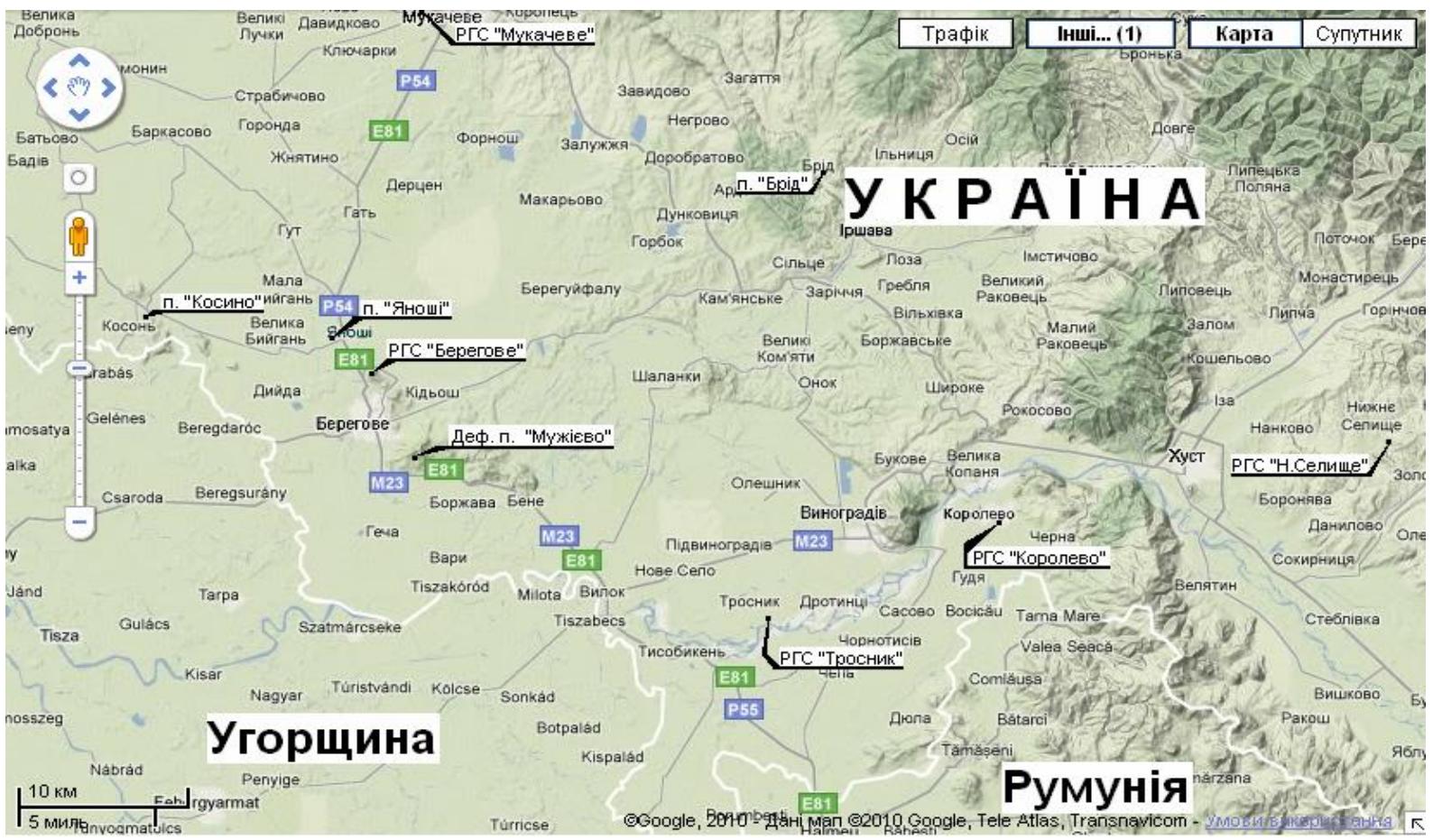

Рис. 1. Розташування пунктів режимних геофізичних спостережень КВ ІГФ НАНУ в центральній частині Закарпаття (на картооснові Google)

Fig. 1. Localization of regime geophysical observations points of the CB IGPh NASU in the central part of Transcarpathians (on the Google maps)

Для формулювання вимог до метрологічних характеристик апаратури проаналізовано дані попередніх [Кутас, Гордиенко, 1971; Кутас, 1978, 2005; Осадчий та ін., 2008; Hvožd'ara et al., 1988; Kalenda et al., 2014] (зокрема наших [Назаревич, Микита, 2010, 2012]) геотермічних досліджень. 3 них відомо, що середні температурні градієнти у свердловинах Карпатського регіону становлять близько 0,03-0,05 ${ }^{\circ} \mathrm{C} / \mathrm{M}$, а в аномальних гідротер- мальних зонах можуть досягати до $0,3-0,5^{\circ} \mathrm{C} / \mathrm{M}$ [Назаревич, Микита, 2012; Назаревич, Назаревич, 2017]. Враховуючи, що скинуті напруження у вогнищах землетрусів здебільшого мають величини від 3 до 40 бар. (у середньому 10 бар), і дані I. Добровольського [Добровольский, 1991] про характер загасання напружень і деформацій під час віддалення від вогнищевої зони, а також результати наших досліджень величин розривів у вогнищах 
місцевих закарпатських землетрусів [Назаревич, 2008; Назаревич, Назаревич, 2009] (довжина розриву відчутного ( $3 \mathrm{~K}=8,5, \mathrm{M}=2,5$ ) місцевого землетрусу оцінена у близько 1 км, розмір його вогнищевої зони - у 3 км, а еквівалентний радіус у 1,5 км), отримуємо на відстанях 15-20 км від вогнища (10 екв. радіусів вогнищевої зони) при підготовці відчутного місцевого землетрусу оцінки величини змін напружень у 0,1 бар і відповідні зміни контрольованої температури на фіксованій глибині від $\pm 0,03-0,05^{\circ} \mathrm{C}$ (під час розміщення геотермічного зонда у зоні звичайних градієнтів) до $\pm 0,3-0,5^{\circ} \mathrm{C}$ (у разі розміщення зонда у високоградієнтній зоні) [Назаревич, Микита, 2012]. Для більших епіцентральних відстаней (наприклад, у 20 радіусів вогнища, або у 30-40 км) коефіцієнт загасання напружень становить порядку 1000, а величини температурних ефектів у свердловинах від $\pm 0,005^{\circ} \mathrm{C}$ до $\pm 0,03-0,05^{\circ} \mathrm{C}$. Отже, застосовувана для таких досліджень свердловинна геотермічна апаратура повинна забезпечувати відповідну глибинність (не менше ніж сотню метрів), чутливість (на рівні $0,001{ }^{\circ} \mathrm{C}$ ) і точність вимірювань температури (на рівні $\pm 0,002-0,005^{\circ} \mathrm{C}$ ).

\section{Свердловинні дослідження геотермічною апаратурою 3 кварцовим термочастотним сенсором}

Враховуючи зазначені вище вимоги, ми розробили високочутливу свердловинну геотермічну апаратуру на базі використовуваної для моніторингу температурного режиму штольні РГС "Берегове" системи 3 кварцовим термочастотним сенсором (рис. 2, а) [Назаревич, Микита, 2010]. Важливою перевагою такої апаратури є те, що у ній вимірювальне перетворення температури у частоту здійснюється безпосередньо в місці вимірювань (у свердловині на відповідній глибині), отже, паразитні впливи довгого каротажного кабеля та багатьох інших факторів на точність вимірювань відсутні. Також позитивним фактором $є$ велика довгочасова стабільність характеристик кварцевого термочастотного сенсора [Малов, 1978].

Як датчики у створеній свердловинній апаратурі використовували термочутливі кварцові резонатори [Малов, 1978; Альтшуллер и др., 1984] 3 робочою частотою 5 МГц, які підмикалися частотозадавальним елементом до схеми електронного автогенератора [Малов, 1978; Альтшуллер и др., 1984; Кончаловский, 1985; Аннюк и др., 1981]. Як вимірювальний прилад використовували прецизійний частотомір-хронометр Ф5041, який забезпечував вимірювання частот з точністю $10^{-7} \mathrm{i}$ 3 розділенням по частоті 0,1 Гц (у режимі інтервалу вимірювання 10 c). Враховуючи, що температурний коефіцієнт частоти $\kappa_{\mathrm{t}}$ (ТКЧ) використаних кварцових датчиків становив приблизно 185 Гц/ ${ }^{\circ} \mathrm{C}$, приведена апаратурна точність вимірювань температури (за частотою) становила $0,0027^{\circ} \mathrm{C}$, а роздільна здатність $\sim 0,0005^{\circ} \mathrm{C}$.

Враховуючи необхідність проведення свердловинних геотермічних досліджень у високоградієнтних зонах - на великих глибинах, де також відсутні приповерхневі метеотемпературні впливи [Фролов, 1966; Назаревич, Микита, 2012; Назаревич та ін., 2016], за результатами відповідних механічних та температурних розрахунків розроблено таку конструкцію зонда (рис. 2, б, в), яка забезпечує його надійну роботу на глибинах у сотні метрів за діючих тисків водяного стовпа у десятки атмосфер, на неї отримано патент на винахід [Патент..., 2016]. Креслення корпуса такого зонда наведено на рис. 2, б, його зовнішній вигляд - на рис. 2, в.

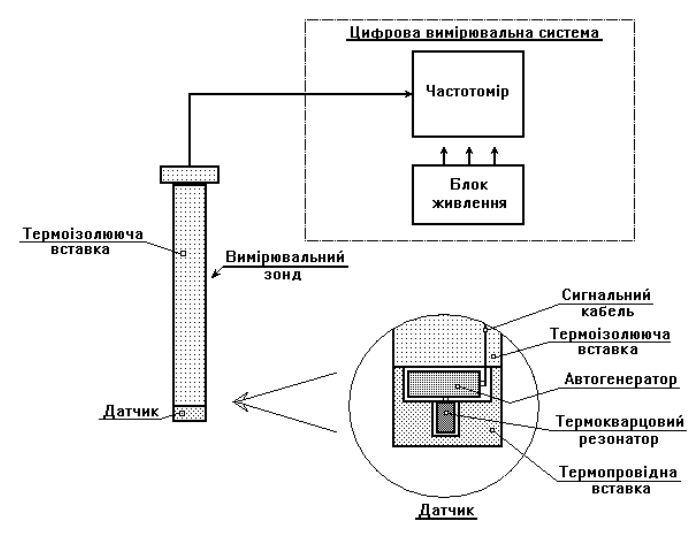

$a$

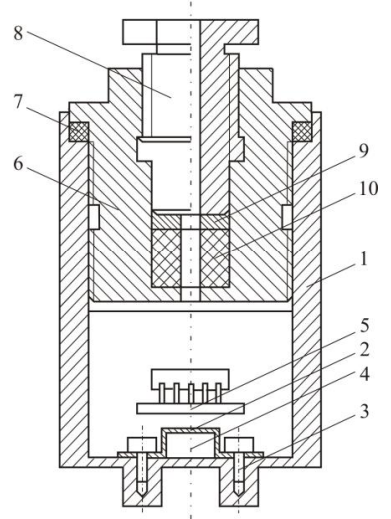

$\sigma$

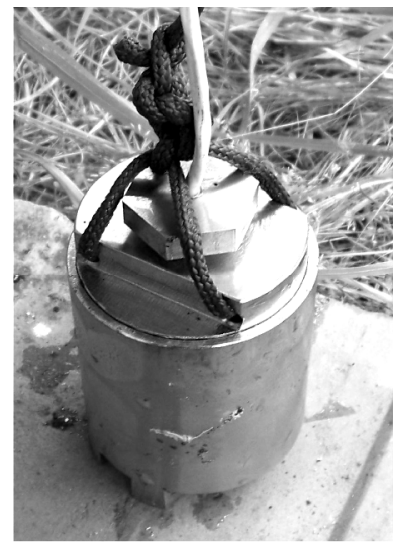

B

Рис. 2. Структурно-функціональна блок-схема вимірювальної системи для геотермічного моніторингу з кварцовим термочастотним датчиком (a) та конструкція (б) [Патент..., 2016] і зовнішній вигляд (в) геотермічного свердловинного зонда (пояснення в тексті)

Fig. 2. Structural-functional block-sheme of the measuring system for geothermal monitoring with a quartz thermo-frequency sensor (a), construction (б) [Patent..., 2016] and appearance (в) of a geothermal well log sonde (explanations are in the text) 


\section{Результати}

Описану вище геотермічну апаратуру ми випробували на ряді свердловин заходу України (у Косино i Троснику на Закарпатті та у Брюховичах поблизу Львова) на глибинах до 500 м [Назаревич, Микита, 2012; Назаревич и др., 2014]. Загалом вона підтвердила свої метрологічні та експлуатаційні характеристики. Водночас проявилася низка проблем та факторів, які обмежують глибинність, досягнення максимальної роздільної здатності та точності вимірювань.

Щодо глибинності це проникання на великих глибинах (за наявних там тисків) рідини у корпус зонда в місці вводу кабеля, а також різьби кришки. Обмеження робочої глибини також спричинялось порівняно значним падінням напруги живлення на довгому (500 м) кабелі і сильним падінням на ньому ж амплітуди високочастотного вимірюваного сигналу (робоча частота кварцового термочастотного сенсора 5 МГц).

Щодо роздільної здатності та точності вимірювань, то одним 3 основних обмежувальних факторів стала виразна теплова інерційність зонда, яка обмежує швидкість термокаротажу (вертикального термопрофілювання свердловини) або його точність при нафтогазопошукових дослідженнях, а також обмежує точність відстеження швидких варіацій температури під час моніторингових досліджень.

За переривчастого режиму роботи свердловинної апаратури проявлявся ще такий фактор, як електротемпературний вплив - встановлення температурного режиму електронної схеми зонда під час ввімкнення живлення. Вплив цього фактора посилювався тим, що в застосовуваній вимірювальній апаратурі (частотомірі-хронометрі Ф5041) не передбачено можливості реалізації режиму синхронізації запуску циклу вимірювань 3 подачею живлення на зонд, що не давало можливості без спеціальних додаткових заходів регуляризувати i надійно редукувати відповідні похибки (див. також нижче).

Хоч два останні фактори спричиняли порівняно невеликі (до $0,05-0,2{ }^{\circ} \mathrm{C}$ ) похибки (див. нижче), все ж вони значно перевищували допустимі і могли за неналежного врахування суттєво знизити якість результатів здійснюваних геотермічних досліджень.

Ще один фактор, який більше впливає на довготривалу точність вимірювань - це порівняно недостатня довгочасова стабільність внутрішнього генератора приладу Ф5041 (1×10\%/доба), що могло спричинити похибку порядку 0,1 Гц/доба (або $\left.\sim 0,0005^{\circ} \mathrm{C} / д о б а\right)$. Для каротажу / термопрофілювання, яке триває, як правило, кілька годин (залежно від глибини свердловини, необхідної детальності та точності зняття температурного профілю (див. нижче)), чи навіть повторного (за тиждень - два - три) це несуттєво, але для моніторингових досліджень тривалістю в місяці і роки це дає дрейф показів за 3 місяці до $0,05{ }^{\circ} \mathrm{C}$, а за рік - до $0,2{ }^{\circ} \mathrm{C}$, тобто на рівні оцінених вище геотемпературних варіацій тектоно-гідрогеологічного походження - провісників місцевих закарпатських землетрусів.

\section{Підвищення глибинності та метрологічних характеристик свердловинної апаратури}

Для покращення метрологічних та експлуатаційних характеристик свердловинної геотермічної апаратури з урахуванням впливу зазначених вище факторів модифіковано конструкцію (рис. 3) та схемотехніку свердловинного зонда і вимірювального каналу.

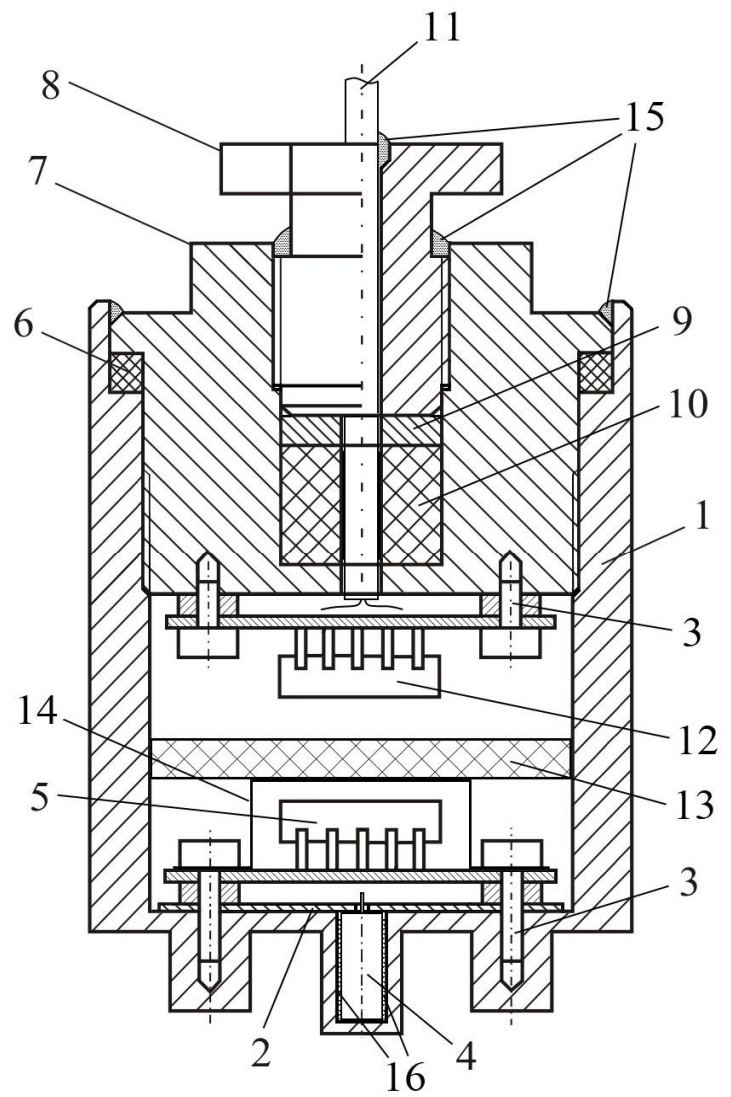

Рис. 3. Конструкція вдосконаленого свердловинного геотермічного зонда (пояснення в тексті).

Fig. 3. Construction of improved geothermal well log sonde (explanations are in the text)

Щодо конструкції зонда - оптимізовано конструкцію кришки 7 і ущільнювального болта 8 для кращої технологічності їх виготування і зручності під час монтування і затискання герметозуючих прокладок 6 і 10 та шайби 9 для забезпечення необхідної герметичності між кришкою 7 та корпусом 1 зонда і кришкою 7 та вводом кабеля 11. Для цього ж у кришці та болті в зонах контакту між собою та 3 корпусом і кабелем передбачено спеціальні пази 15, в які заливається герметиккомпаунд. Він додатково герметизує зони кон- 
такту цих конструктивних елементів зонда між собою, підвищуючи надійність його роботи на великих (сотні і тисячі метрів) глибинах у свердловинах за діючих там тисків рідини 20-100 бар і більше та за високих (до $70-120{ }^{\circ} \mathrm{C}$ і більше) температур, але водночас залишає можливість розібрати зонд за необхідності його ремонту чи модифікації.

Ще одне важливе вдосконалення конструкції корпуса зонда - спеціальний виступ по центру його дна, в якому 3 внутрішнього боку вифрезеровано гніздо для кварцового термосенсора 4. Стінки цього гнізда мають мінімальну необхідну товщину, щоб забезпечити, з одного боку, найкращий тепловий зв'язок сенсора 3 зовнішнім середовищем (рідиною у свердловині), а 3 ін.шого - необхідну міцність і стійкість до деформування під гідростатичним тиском цієї рідини (у десятки і перші сотні бар) у свердловині на великих глибинах. Підвищеній стійкості до деформування також сприяють малі лінійні розміри стінок гнізда (мінімальна площа навантаження тиском рідини), і їхня форма, де вони та кути між ними виконують роль ребер жорсткості. Кварцовий сенсор фіксується (затискається) у гнізді за допомогою планки 2 тими ж болтами 3 , що фіксують модуль генератора 5.

Надійний тепловий контакт між нижньою торцовою та всіма боковими стінками кварцового сенсора і відповідними стінками гнізда забезпечується за рахунок заповнення гнізда в'язкою теплопровідною субстанцією 16, наприклад термопастою КТП-8 чи ін. Таке конструктивне рішення (термосенсор у спеціальному гнізді у виступі дна корпуса зонда, тобто як спеціальний термощуп) забезпечує кратне зниження еквівалентної теплової інерційності зонда (і відповідне підвищення його “швидкодіі”, чутливості та точності), за рахунок того, що забезпечено практично всесторонній тепловий контакт кварцового термосенсора 3 контрольованим середовищем. Також одночасно забезпечується мінімальний паразитний електротемпературний вплив на термосенсор з боку електронної схеми зонда (детальніше див. далі).

Модифікація електричної схеми зонда полягала, насамперед, у застосуванні цифрового дільника частоти 12 (рис. 3), який кратно (у 5/10/20 чи більше разів) знижує частоту вимірюваного сигналу 3 кварцового термосенсора (5 МГц), що подається на кабель, забезпечуючи тим самим можливість передачі цього сигналу на відстані у сотні і тисячі метрів. Зауважимо, що при цьому для досягнення максимальної $\left(10^{-8}\right)$ точності вимірювань частоти/температури необхідно відповідно кратно збільшувати часовий інтервал вимірювання. Так, під час наших експериментальних свердловинних досліджень (див. нижче) інтервал вимірювання становив 100 с. Це переважно не критично, оскільки теплові процесі і так мають свою часову інерційність.
Для уникнення за таких вимірювань похибок, пов'язаних 3 тепловою інерційністю зонда i несинхронністю вимірювань реалізовано режим синхронізації вимірювального каналу з моментами початку контакту зонда зі середовищем у контрольованій точці (див. далі), або (за неможливості такої синхронізації) - спосіб визначення i врахування відповідних таймінгових температурних поправок/інтервальних зміщень (див. також нижче).

Для тих самих випадків, коли необхідно відстежувати 3 великою точністю і роздільною здатністю швидкі зміни температури (наприклад, термокаротаж/термопрофілювання свердловин 3 можливістю достатньо швидкого (на рівні $0,1 \mathrm{~m} / \mathrm{c}$ i більше) опускання зонда і з забезпеченням роздільної здатності і точності профілювання не гірше $\left.0,01-0,05^{\circ} \mathrm{C}\right)$, запропоновано проводити точне вимірювання частоти кварцового термосенсора за допомогою мультикратного вимірювання періоду сигналу з подальшим перерахунком у частоту (вимірювання періоду з багатократним $\left(10^{5}-10^{7}\right)$ нагромадженням, аналогічно, як це реалізовано в контрольному (частотному) каналі цифрового мультиканального фазометра розробленої нами геоакустичної апаратури АЦГК-1 та іiі модифікацій [Назаревич, 1988, 2011]).

У зв'язку з доповненням електронної схеми зонда дільником частоти стало можливим значно оптимізувати схемотехніку зонда, забезпечивши багатократне зниження споживаної ним потужності, відповідних електротемпературних впливів та похибок, підвищити чутливість, точність i, особливо (на порядок та більше), довготривалу часову стабільність (мінімізований часовий дрейф) його метрологічних характеристик, а також практично зняти обмеження на довжину сигнальноживильного кабеля (як по сигнальних, так і по живильних лініях). Для цього використано схемотехнічні напрацювання, які ми отримали під час розроблення служби часу та стандартних частот геоакустичної апаратури АЦГК-1 (АЦГК-1/01, АЦСГК-2), зокрема, базового високоточного термостабілізованого генератора опорної частоти [Назаревич, 1988]. Такий генератор (оскільки його довготривала часова нестабільність не перевищує $0,5-1 \times 10^{-9}$ на добу, тобто є на порядок кращою, ніж, наприклад, у використовуваного нами для пробних свердловинних досліджень частотомірахронометра Ф5041 $\left.\left(10^{-8}\right)\right)$ також запропоновано використати як зовнішній задаючий генератор для використовуваних частотомірів чи спеціально розробленої частото/періодомірної системи.

3 урахуванням модифікації схемотехніки зонда 3 виокремленнам схеми термовимірювального генератора 5 в окремий модуль, цей модуль конструктивно доповнено також електромагнітним 14 та тепловим 13 екранами для нейтралізації можливих відповідних впливів модуля дільника i кабельного інтерфейсу 12 на модуль генератора 5. 
Дослідження та редукція теплової інерційності свердловинного зонда на дані свердловинного геотермопрофілювання

Під час термопрофілювання свердловин у Косино, Брюховичах і Троснику, як уже відзначалося вище, помітно проявилася теплова інерційність першого варіанта (рис. 2) створеного нами свердловинного зонда (див. також нижче). Тому для отримання “істинних" температурних профілів свердловин ми провели спеціальні дослідження i розробили наведену нижче методику редукції теплової інерційності свердловинного зонда.

Підхід до розв'язання цієї задачі такий - на основі порівняння відомих у загальному вигляді [Чекалюк и др., 1974; Назаревич и др., 2014] часових залежностей між температурою зонда (виміряною сенсором) і часом - так званих теплових перехідних процесів - встановлено такі величини, як температурно-часова постійна зонда $\tau_{t}$, а далі для конкретних вимірювань методом найменших квадратів та 3 використанням ітераційних процедур знаходили рівняння регресії для теплового перехідного процесу, які найкраще (3 урахуванням похибок вимірювань) задовольняли спостереженим даним. За цими рівняннями будувалися (продовжувалися в часі) криві становлення температурного режиму зонда аж до стаціонарних значень (3 точністю до $0,0001{ }^{\circ} \mathrm{C}$ ), за цими значеннями будувалися “істинні” температурні профілі досліджених свердловин. Такі дослідження проводились 3 використанням напрацьованих нами під час аналізу каротажних даних

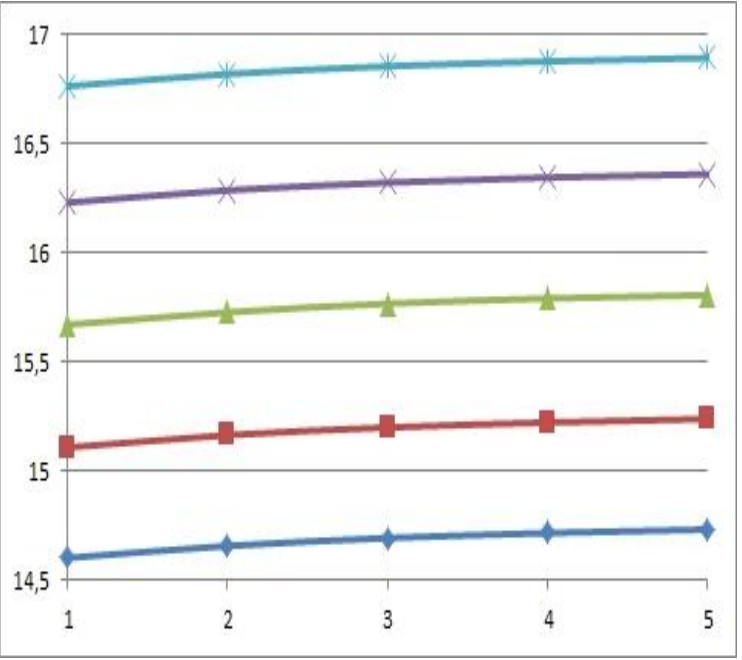

нафтогазопошукових досліджень підходів та методик і можливостей програмного продукту Excel [Скакальська та ін., 2017].

Суть методики показано нижче на прикладі опрацювання даних термопрофілювання верхньої частини свердловини № 16-п Косинського родовища термальних вод.

Для отримання якнайкращих результатів спочатку відкориговано первинні дані термокаротажу свердловини № 16-п за апаратурно-часові інтервальні затримки вимірювань (так звані інтервальні зміщення), пов'язані, зокрема, як 3 особливостями методики досліджень, так і 3 особливостями функціонування використовуваного частотоміра-хронометра Ф5041 у режимі нагромадження даних з великими інтервалами вимірювань. Отримані відкоректовані криві становлення (для глибин 20/30/40/50/60 м, тобто для вимірювань у воді) і графіки відповідних часових градієнтів для цієї свердловини наведено на рис. 4 .

Далі для кожної кривої становлення (для кожної 3 перелічених глибин) визначалися коефіцієнти рівняння регресії, записаного в загальному вигляді у такій формі:

$$
{ }_{i} t^{o}={ }_{0} t^{o}+\Delta t^{o}\left(1-e^{-t / \tau}\right)
$$

де ${ }_{i} t^{\circ}-$ шукана температура на конкретній глибині (залежна від часу вимірювань); ${ }_{o} t-$ початкова температура зонда для вимірювань на конкретній глибині; $t$ - час вимірювання в умовних інтервалах (у нашому випадку - в інтервалах накопичення); $\tau_{t}$ - температурно-часова постійна зонда (в умовних інтервалах).

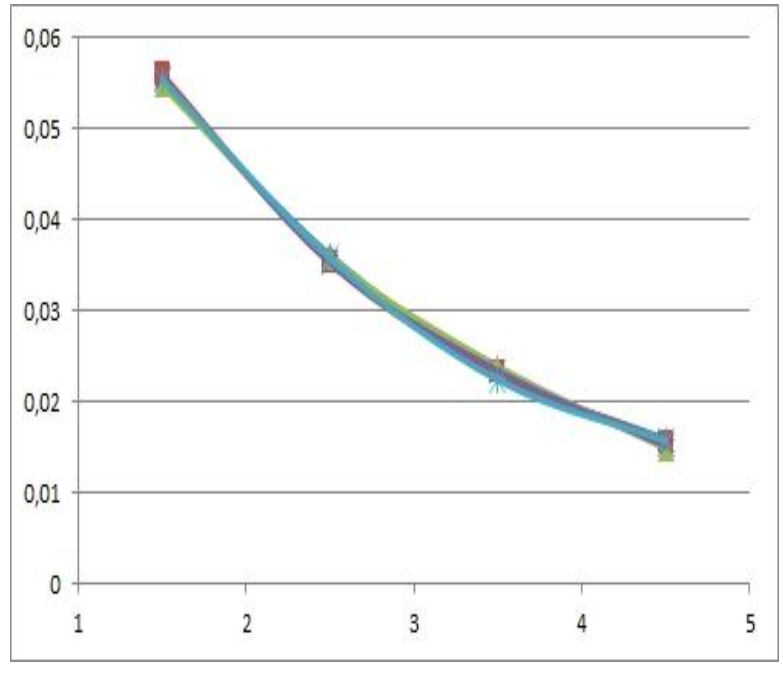

$\sigma$

Рис. 4. Відкоректовані за апаратурно-часові затримки (інтервальні зміщення) дані термопрофілювання свердловини № 16-п Косинського родовища термальних вод: $a$ - графіки становлення температури зонда на глибинах 20/30/40/50/60 м (у воді); $\sigma$ - графіки відповідних часових температурних градієнтів

Fig. 4. Corrected for hardware-time delays (interval offsets) data of thermal profiling wells No 16-p Kosyno hydrothermal field: a - graphs of the sonde temperature time-changes at depths 20/30/40/50/60 m (in water); $b$ - graphs of the corresponding time temperature gradients 
У першому наближенні значення $\tau_{t}$ бралося для всіх випадків однаковим. Пізніше виявилось (див. нижче), що для різних глибин кращий між теоретичною та експериментальною кривою отримується за дещо різних $\tau_{t}$. Це, очевидно, пов'язано 3 певною зміною солоності/густини рідини у свердловині з глибиною і відповідною зміною умов теплопередачі від рідини до зонда. Отже, за даними досліджень, температурна стала для зонда $\tau_{t}=2,5(2,4)(\times 100$ c), тобто $250(240)$ с.

Розроблення методики детально розглянемо на прикладі даних для глибини 20 м (рис. 5). Тут, на (рис. 5, a), наведено графік становлення температури зонда на глибині 20 м і графік апроксимаційної функції. Саму функцію визначено такою:

$$
{ }_{i} t^{\circ}=14,522+0,2425\left(1-e^{-t / 2,5}\right)\left({ }^{\circ} \mathrm{C}\right) .
$$

На рис. 5, б наведено графік відхилень між кривою становлення температури зонда і побудованою апроксимаційною функцією (2). Бачимо, що у діапазоні інтервалу вимірювань (до 500 с) відхилення між ними не перевищують $\pm 1,3$ міліградуса і зі зростанням часу вимірювань
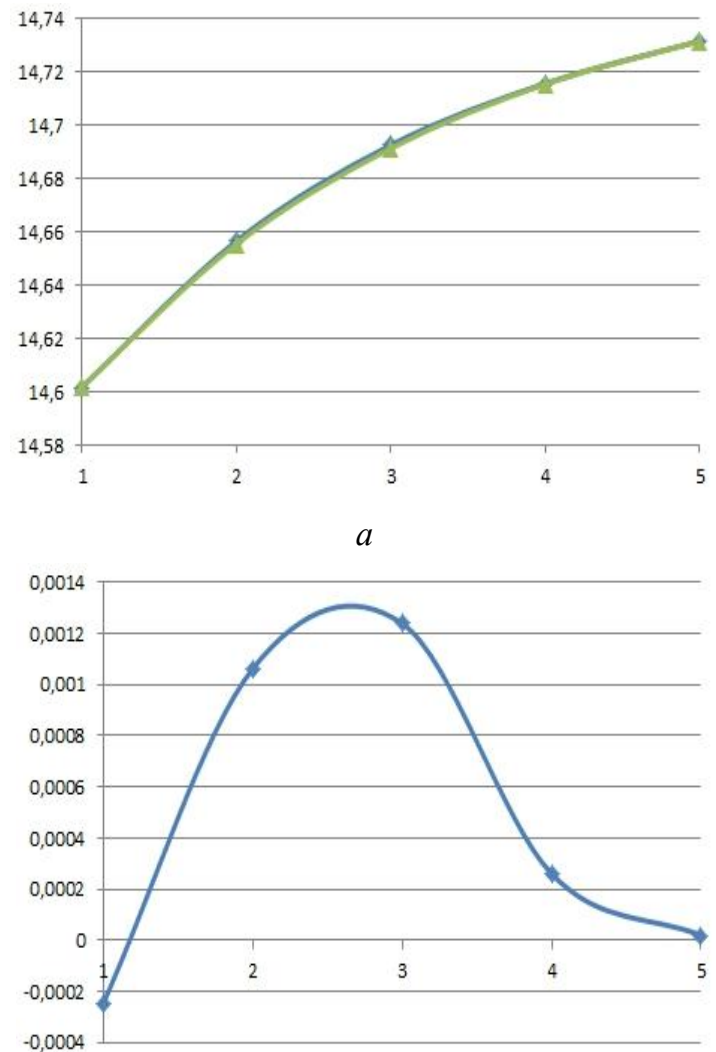

$\sigma$ (рис. 5, в) прямують до нуля. На рис. 5, в, крім екстраполяційного графіка 1 відхилень між кривою становлення температури зонда і апроксимаційною функцією (екстраполяція до 40 хв), наведено і графік 2 відхилень екстраполяційної функції перехідного температурного процесу від температури стаціонарного режиму (обидва - у логарифмічному масштабі).

Аналогічно проведено дослідження і для глибин 30/40/50/60 м. Апроксимаційні функції для цих глибин визначено такими:

$$
\begin{aligned}
& { }_{i} t^{\circ}=15,0294+0,2425\left(1-e^{-t / 2,5}\right)\left({ }^{\circ} \mathrm{C}\right) ; \\
& { }_{i} t^{o}=15,586+0,2519\left(1-e^{-t / 2,4}\right)\left({ }^{\circ} \mathrm{C}\right) ; \\
& { }_{i} t^{\circ}=16,1485+0,2435\left(1-e^{-t / 2,4}\right)\left({ }^{\circ} \mathrm{C}\right) ; \\
& { }_{i} t^{\circ}=16,682+0,2435\left(1-e^{-t / 2,4}\right)\left({ }^{\circ} \mathrm{C}\right) .
\end{aligned}
$$

Результати цих досліджень наведено на рис. 6. На рис. 6, а подано графіки апроксимаційних функцій для глибин 20/30/40/50/60 м і кривих становлення температури зонда для тих самих глибин. На рис. 6, б наведено графіки відхилень між кривими становлення температури зонда і побудованими апроксимаційними функціями (2)-(6).
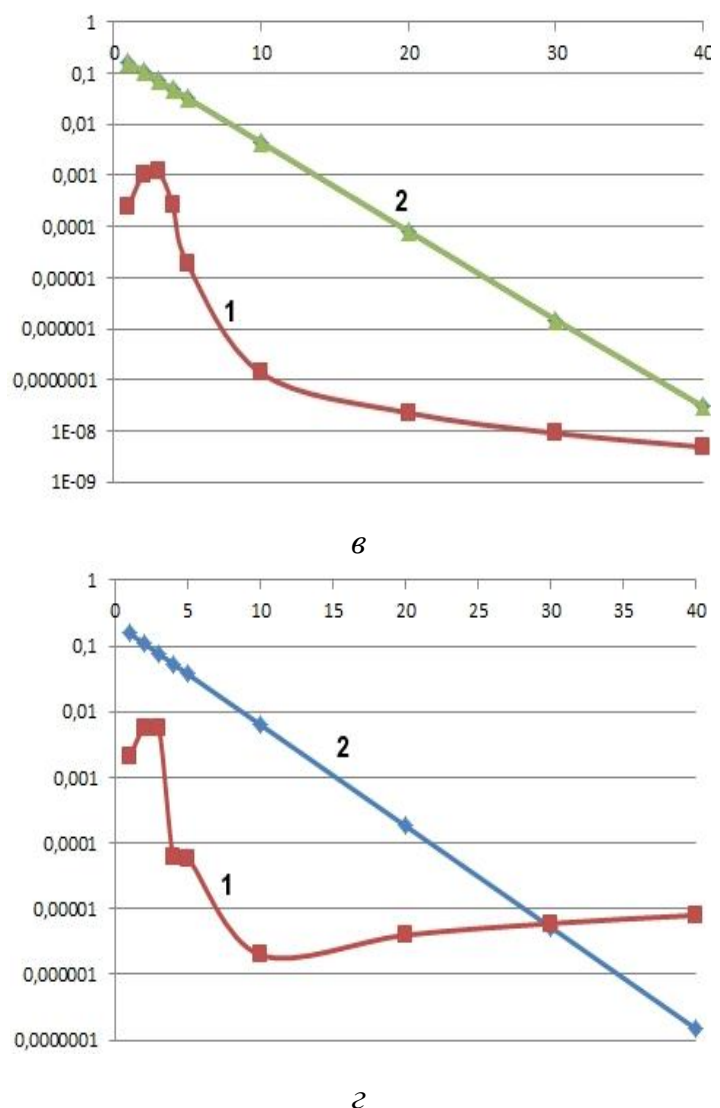

Рис. 5. Результати дослідження та редукції температурної інерційності свердловинного зонда (на прикладі даних свердловини № 16-п Косинського родовища термальних вод (пояснення в тексті)

Fig. 5. Results of studies and reduction of temperature inertia of the well log sonde (on example the data of well No 16-p of Kosyno hydrothermal field (explanations are in the text) 

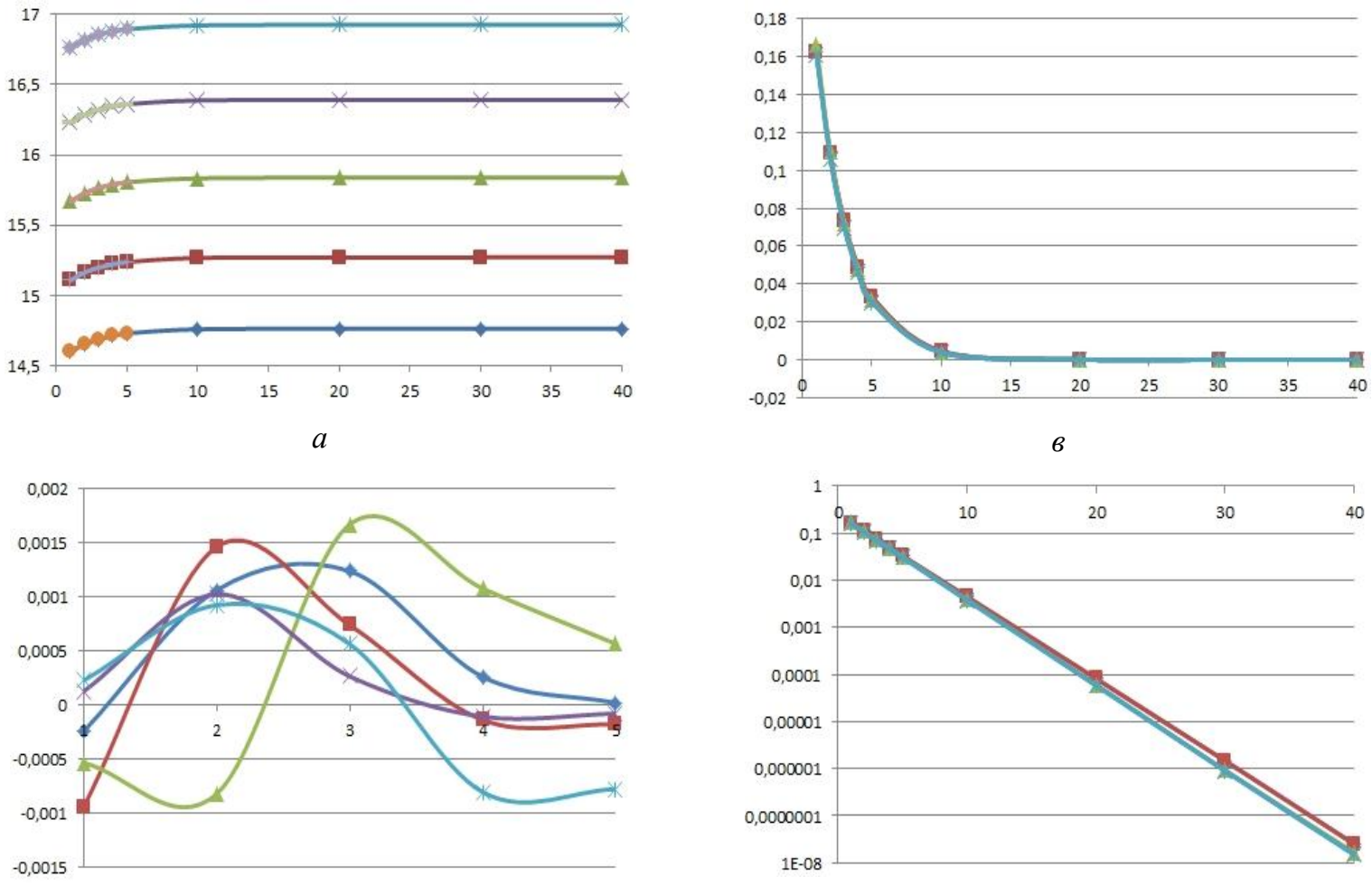

$\sigma$

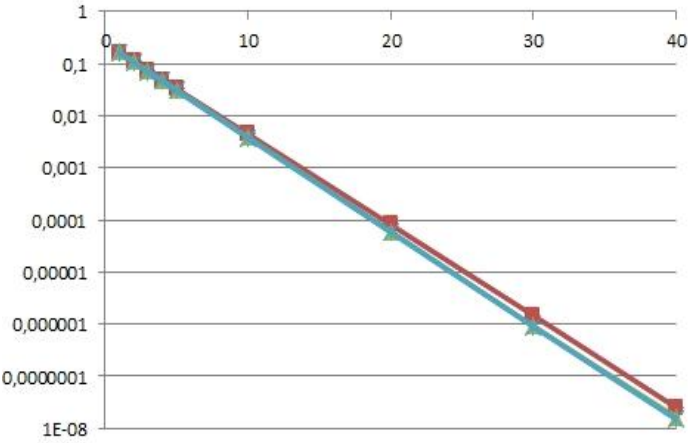

Рис. 6. Результати дослідження та редукції теплової інерційності свердловинного зонда (на прикладі даних свердловини № 16-п Косинського родовища термальних вод) (пояснення в тексті)

Fig. 6. Results of studies and reduction of temperature inertia of the well log sonde (on example the data of well No 16-p of Kosyno hydrothermal field (explanations are in the text)

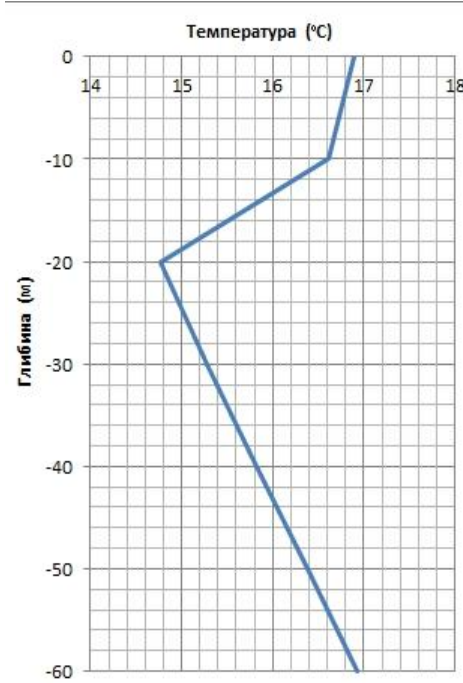

$a$

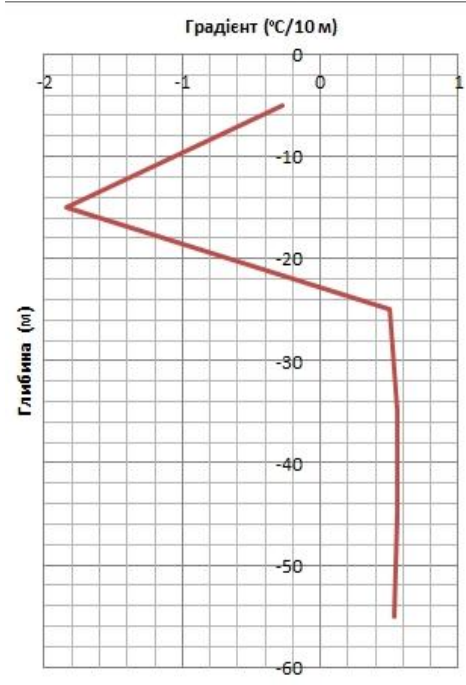

$\sigma$



B

Рис. 7. Відкоректовані за температурну інерційність свердловинного зонда дані термопрофілювання свердловини № 16-п Косинського родовища термальних вод: уточнений температурний профіль свердловини (а), профіль температурного градієнта (б) і профіль відхилень виміряних значнь температури від розрахованих (профіль поправок) (в)

Fig. 7. Corrected for the temperature inertia of the well log sonde the data of the thermal profile of the well No 16-p of Kosyno hydrothermal field: refined temperature profile of the well (a), the profile of the temperature gradient (б) and the profile of deviations of the measured temperature values from the calculated (profile of corrections) ( 8$)$ 
Бачимо, що у діапазоні інтервалу вимірювань (до 500 с) відхилення між ними не перевищують $\pm 1,7$ міліградуса і зі зростанням часу вимірювань (рис. 6, б-2) прямують до нуля; (рис. 6, в) - відхилення між екстраполяційною функцією перехідного температурного процесу та температурою стаціонарного режиму у лінійному масштабі; (рис. 6,2 ) - те саме у логарифмічному).

Зазначимо, що “істинна" температура на глибині Н $є$ такою:

$$
{ }_{i} t^{\circ}={ }_{o H} t^{\circ}+{ }_{H} \Delta t^{\circ} .
$$

Температурний градієнт $\partial_{H} t / \partial H$ для глибини $H$ визначається як:

$$
\begin{aligned}
& \partial_{H} t^{o} / \partial H=\left(\left(H^{o}{ }^{o}{ }_{H} \Delta t^{o}-{ }_{H-1} t^{o}-H-1 \Delta t\right)+\right. \\
& \left.+\left(H+1+t^{o}+{ }_{H+1} \Delta t-_{-H} t{ }_{-H} \Delta t\right)\right) / 2 .
\end{aligned}
$$

Уточнений (з урахуванням теплової інерційності свердловинного зонда) температурний профіль свердловини наведено на рис. 7, a), вертикальні температурні градієнти (різниці між значеннями ${ }_{H} t^{\circ}$ у формулах (2)-(6)) - на рис. 7, б), а відхилення виміряних значнь температури від розрахованих (профіль поправок) - на рис. 7, в).

3 цих результатів бачимо, що для свердловини в Косино поправки за інерційність зонда $є$ невеликими (у воді менше ніж 0,017 ${ }^{\circ} \mathrm{C}$ (для всіх глибин)). Це тому, що за рахунок досить вдалої конструкції зонда його теплова інерційність $€$ порівняно невеликою $\left(\tau_{t}=250 \mathrm{c}\right)$, а на кожній глибині вимірювання проводились досить тривалий час $\left(500 \mathrm{c}\right.$, тобто $\left.2 \tau_{t}\right)$

\section{Результати експериментальних свердловинних досліджень}

3 використанням описаної свердловинної геотермічної апаратури 3 кварцовим термочастотним сенсором (у різних модифікаціях) та відповідних методик досліджень і опрацювання результатів проведено низку експериментальних досліджень, зокрема, термопрофілювання гідротермальних свердловин у Косино і Троснику на Закарпатті та у Брюховичах поблизу Львова, а також режимні моніторингові спостереження у Косино i експериментальні моніторингові дослідження у Брюховичах та Троснику. Результати проведених раніше (2010-2011 рр.) у Косино моніторингових досліджень уже частково опубліковано [Назаревич, Микита, 2012], результати проведеного там же термопрофілювання верхньої частини досліджуваної свердловини подано на рис. 8 (первинні криві становлення температури зонда на різних глибинах (з кроком за глибиною 10 м), зокрема у сухій та обводненій зонах), а їхній детальний аналіз наведено вище, саме на їх основі досліджено та застосовано температурні поправки за теплову інерційність свердловинного зонда.

Далі коротко представимо результати досліджень (термопрофілювання) на свердловинах у Брюховичах і Троснику.

Дослідження, зокрема, термопрофілювання у Брюховичах проводились кількаразово 3 метою відпрацювання свердловинної апаратури. У підсумку досягнуто надійної роботи зонда (враховуючи багатодобові моніторингові дослідження) на максимальних глибинах 500 м, обмежених довжиною наявного сигнального кабеля. Отриманий результуючий температурний профіль свердловини (з урахуванням ряду апаратурних i методичних поправок) наведено на рис. 9.

Аналізуючи коротко ці дані, треба зауважити, що, крім не особливо цікавих для геофізики особливостей змін температури на приповерхневих глибинах до 60 м (у необводненій частині свердловини), звертає на себе увагу дещо більший $\left(0,305 \pm 0,015^{\circ} \mathrm{C} / 10\right.$ м) температурний градієнт на порівняно невеликих глибинах (в інтервалі 80-210 м), тоді як глибше (в інтервалі 230-500 м) цей

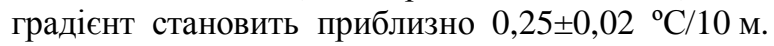
Причинами цього можуть бути особливості геологічного розрізу цієї свердловини, це питання потребує подальших досліджень.

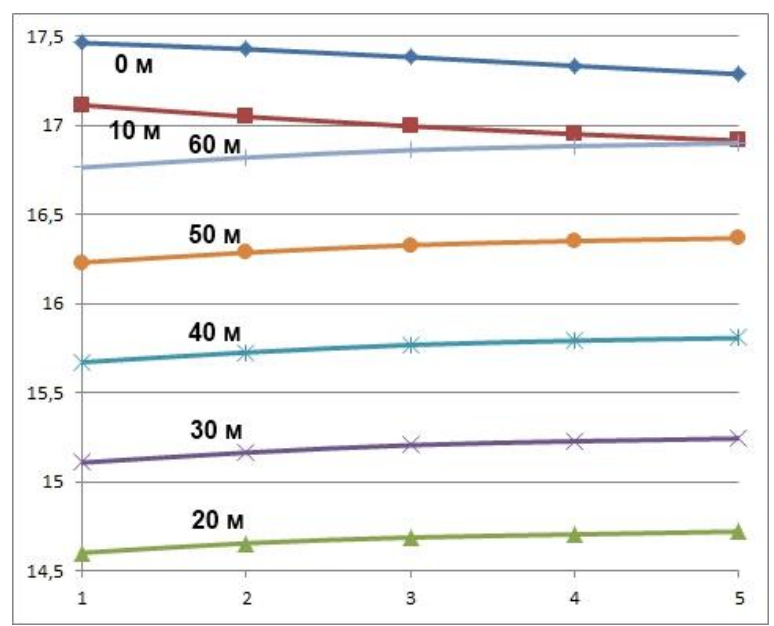

Рис. 8. Результати термопрофілювання верхньої частини гідротермальної свердловини № 16-п Косинського родовища термальних вод - графіки становлення температури зонда на різних глибинах

Fig. 8. Results of thermal profiling of the upper part of the hydrothermal well No. 16-p of the Kosyno hydrothermal field - graphs of sonde temperature time-changes at different depths

Дослідження за допомогою відпрацьованої під час робіт на свердловині у Брюховичах апаратури проведено також на свердловині у Троснику у Закарпатті. Отриманий температурний профіль свердловини наведено на рис. 10.

Аналізуючи отримані дані, зазначимо, що рівень води у цій свердловині міститься на глибині 1,15 м від поверхні, отже, тільки точка 3 глибиною 0 м виміряна у повітрі відповідає метеотемпературі на поверхні грунту, решта точок - це вимірювання у воді. На графіках рис. 10 чітко виділяються 2 інтервали глибин 3 різко 
відмінними градієнтами температури. Перший інтервал - від 20 м до 110 м (в інтервалі 0-20 м ще наявний вплив сезонної метеотемпературної складової), він характеризується низьким градієнтом - 0,009-0,02 ${ }^{\circ} \mathrm{C} /$ м. Другий інтервал від 140 до 250 м, на ньому температурний градієнт має величину $0,05-0,07^{\circ} \mathrm{C} / \mathrm{M}, \quad$ на перехідних

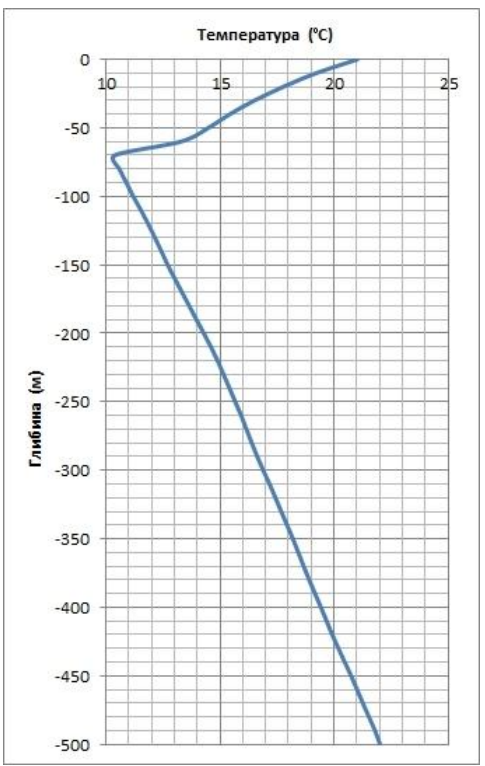

$a$ глибинах між цими інтервалами (110-140 м) температурний градієнт наростає від 0,025 до $0,045{ }^{\circ} \mathrm{C} / \mathrm{M}$. Починаючи 3 глибини 300 м, температурний градієнт потроху плавно знижується (з певними варіаціями) $30,065^{\circ} \mathrm{C} / \mathrm{M}$ до $0,058^{\circ} \mathrm{C} / \mathrm{M}$ на глибинах $400-440$ м і до $0,048^{\circ} \mathrm{C} / \mathrm{M}$ на глибинах 480-500 м.

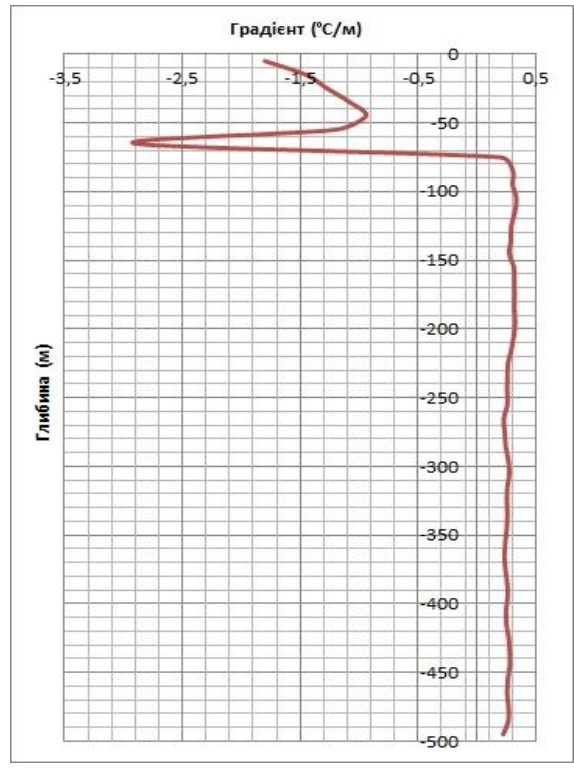

$\sigma$

Рис. 9. Температурний профіль свердловини Брюховичі-1 до глибини 500 м (а) та відповідний профіль температурного градієнта (у ${ }^{\circ} \mathrm{C} / 10$ м) (б) (дані 4-го циклу досліджень)

Fig. 9. Temperature profile of the Bryukhovychi-1 well to the depth of $500 \mathrm{~m}$ (a) and the corresponding profile of the temperature gradient $\left({ }^{\circ} \mathrm{C} / 10 \mathrm{~m}\right)$ (б) (data of the 4th cycle of studies)

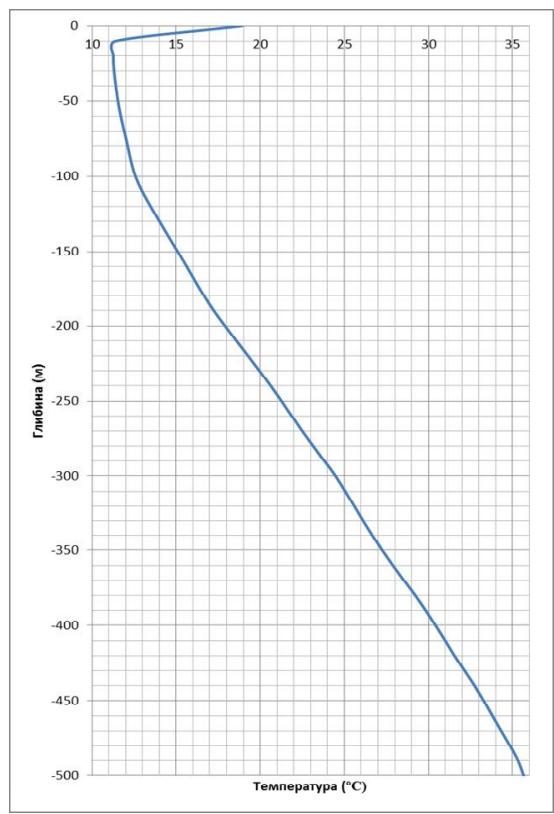

$a$

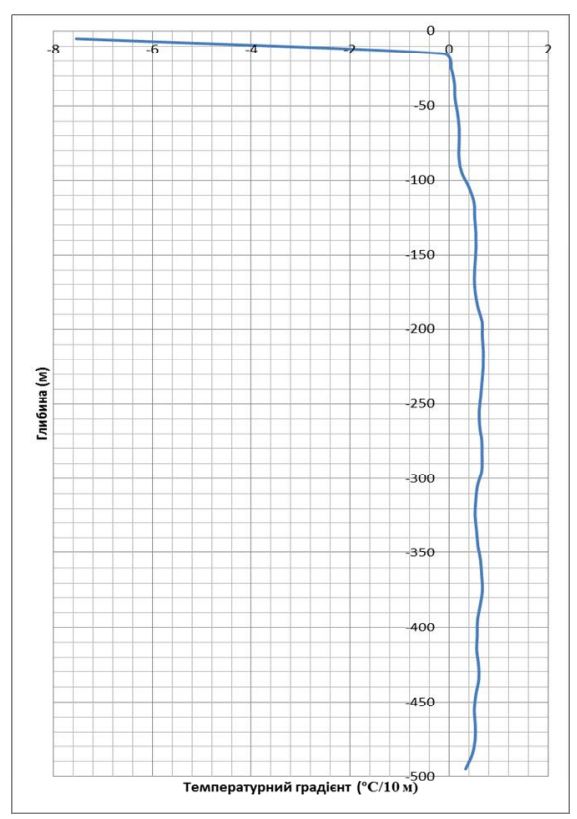

$\sigma$

Рис. 10. Температурний профіль свердловини № 838 на РГС “Тросник”до глибини 500 м (а) та відповідний профіль температурного градієнта (у ${ }^{\circ} \mathrm{C} / 10$ м) (б) (дані 3-го циклу досліджень)

Fig. 10. Temperature profile of the well No 838 in the RGS "Trosnyk" to the depth of $500 \mathrm{~m}$ (a) and the corresponding profile of the temperature gradient $\left({ }^{\circ} \mathrm{C} / 10 \mathrm{~m}\right)$ (б) (data of the 3th cycle of studies) 
Зведені дані геотемпературних досліджень у сведловинах Карпатського регіону

Summary data of geothermal studies in the wells of the Carpathian region

\begin{tabular}{|c|c|c|c|}
\hline \multirow{2}{*}{$\begin{array}{c}\text { Глибина } \\
\text { (м) }\end{array}$} & \multicolumn{3}{|c|}{$\begin{array}{c}\text { Свердловина } \\
\text { температура/градієнт }\end{array}$} \\
\hline & Косино & Брюховичі & Тросник \\
\hline 50 & $16,4 / 0,054$ & - (повітря) & $12,75 / 0,009$ \\
\hline 100 & - & $11,19 / 0,0335$ & $13,5 / 0,022$ \\
\hline 150 & - & $12,70 / 0,0313$ & $15,75 / 0,053$ \\
\hline 200 & - & $14.29 / 0,0312$ & $18,5 / 0,056$ \\
\hline 250 & - & $15,67 / 0,0258$ & $21,3 / 0,055$ \\
\hline 300 & & $16,90 / 0,0275$ & $24,5 / 0,065$ \\
\hline 350 & & $18,19 / 0,0241$ & $27,2 / 0,058$ \\
\hline 400 & & $19,43 / 0,0246$ & $30,4 / 0,062$ \\
\hline 450 & & $2075 / 0,0261$ & $33,3 / 0,058$ \\
\hline 500 & & $22,02 / 0,0267$ & $35,7 / 0,048$ \\
\hline $\begin{array}{c}\text { Досліджений } \\
\text { діапазон глибин / } \\
\text { з них у воді }\end{array}$ & $\begin{array}{c}0-60 \mathrm{~m} / \\
15,3-60 \mathrm{M}\end{array}$ & $\begin{array}{c}0-500 \mathrm{M} / \\
68,5-500 \mathrm{M}\end{array}$ & $\begin{array}{c}0-500 \mathrm{~m} / \\
1-500 \mathrm{M}\end{array}$ \\
\hline $\begin{array}{c}\text { *Температура на } \\
\text { (мін.)/(макс.) глибині }\end{array}$ & $\begin{array}{l}14,72^{\circ} \mathrm{C}(20 \mathrm{~m}) / \\
16,90^{\circ} \mathrm{C}(60 \mathrm{~m})\end{array}$ & $\begin{array}{l}10,38(70 \mathrm{~m}) / \\
22,02(500 \mathrm{~m})\end{array}$ & $\begin{array}{c}11,379^{\circ} \mathrm{C}(10 \mathrm{M}) / \\
35,6536^{\circ} \mathrm{C}(500 \mathrm{~m})\end{array}$ \\
\hline $\begin{array}{c}\text { *Різниця температур / } \\
\text { *Середній } \\
\text { температурний } \\
\text { градієнт }\end{array}$ & $\begin{array}{c}2,18^{\circ} \mathrm{C} / \\
0,0545^{\circ} \mathrm{C} / \mathrm{M}\end{array}$ & $\begin{array}{c}11,79^{\circ} \mathrm{C} / \\
0,027^{\circ} \mathrm{C} / \mathrm{M}\end{array}$ & $\begin{array}{c}24,28^{\circ} \mathrm{C} / \\
0,0496^{\circ} \mathrm{C} / \mathrm{M}\end{array}$ \\
\hline
\end{tabular}

* В обводненому інтервалі глибин

Відзначимо, що дані цих досліджень повністю узгоджуються 3 даними, отриманими тут раніше P. I. Кутасом [Кутас, 2005] - за його даними температура у свердловині на цій глибині мінялася впродовж 1992-1997 pp. у межах 34,5-34,7 ${ }^{\circ} \mathrm{C}$, за нашими даними у 2015-2016 рр. цю температуру визначено у $35,584{ }^{\circ} \mathrm{C}\left(35,6536{ }^{\circ} \mathrm{C}\right.$ з урахуванням теплової інерційності зонда).

Порівняльний наліз результатів свердловинних геотермічних досліджень. Порівнюючи дані досліджень перелічених сведловин (зведені у табл. 1), можемо відзначити, що найвищі градієнти на невеликих (50 м) глибинах є у свердловині Косино, а найнижчі - у Троснику. У свердловині у Брюховичах градієнти по всьому розрізу є середніми (близько $0,03{ }^{\circ} \mathrm{C}$ ) і міняються мало (до 1,3 раза, у межах $0,025-0,033{ }^{\circ} \mathrm{C} / \mathrm{M}$ ), а у свердловині в Троснику - $\epsilon$ найбільш змінними (у 7 разів, від 0,009 на глибинах 20-50 м до 0,065-0,067 ${ }^{\circ} \mathrm{C} / \mathrm{м}$ на глибинах 200-400 м). Причини таких різкозмінних градієнтів у Троснику (зокрема, дуже низьких градієнтів у приповерхневих (20-50 м) горизонтах) потребують подальших досліджень. Зазначимо також, що градієнти, які ми визначили, за верхньою частиною свердловини у Косино і за нижньою частиною свердловини у Троснику є такими ж або близькими до тих, які визначені для закарпатських гідротермальних свердловин спеціалістами Закарпатської ГРЕ (Р. С. Жарнікова) - близько $0,05^{\circ} \mathrm{C} /$ м. Ще зауважимо, що температурні градієнти у свердловинах у Брюховичах і у Троснику на більших глибинах дещо знижуються, у Брюховичах - 3 глибини 220230 м, а у Троснику - 3 300-310 м, порівняно 3 максимальними значеннями на глибинах 150-200 i 200-250 м відповідно.

Причинами різних температурних градієнтів на різних глибинах у досліджених свердловинах можуть бути як різна теплопровідність порід розрізу - як власна, так і за рахунок різної їх обводненості, а значить, різного вкладу (поряд 3 теплопровідним / кондуктивним) і конвективного теплоперенесення [Кутас, 1978; Чекалюк и др., 1974], так i “"заморожені” на більших глибинах довгоперіодні температурні хвилі, пов’язані зі змінами клімату [Кутас, 1978; Kalenda et al., 2014], або ще інші фактори, це питання потребує подальших досліджень.

\section{Врахування температурних впливів на результати геофізичних спостережень}

3 температурним впливом на результати геофізичних, зокрема, деформографічних сейсмопрогностичних досліджень, вчені борються вже давно ([Латынина и др., 1988; Вербицький, Назаревич, 2005; Назаревич и др., 2007; Назаревич, 2011] та ін.). Один з підходів до вирішення цієї проблеми проведення температурного моніторингу на пункті спостережень $з$ подальшим вивченням і редукцією виявлених метеотемпературних впливів [Назаревич, 2011]. 
Один 3 варіантів методики врахування сезонних метеотемпературних впливів для виділення малоамплітудних геофізичних, зокрема, деформаційних провісників місцевих закарпатських землетрусів розроблено нами і представлено нижче на прикладі аналізу даних деформографа "Мужієво”.

Дослідження на пункті "Берегове-1" ("Мужієво") проводили Л. О. Латиніна, О. Г. Юркевич та I. М. Байсарович [Латынина и др., 1992]. Сама деформографічна станція (географічні координати $\varphi=48,2^{\circ}, \lambda=22,7^{\circ}$ ) розташована у розвідувальній штольні № 22 [Латынина и др., 1992; Назаревич и др., 2007] на південному схилі гори Мужіївської (Великої Берегівської) у підніжжі її вершинного купола, за 3 км на південнй схід від м. Берегове (рис. 11). Тут встановлені 2 горизонтальні кварцові деформографи завдовжки 28 м (азимут $37^{\circ}$ ) і 12 м (азимут $73^{\circ}$ ), розташовані у відокремленому від решти штольні відсіку довжиною близько 150 м. Відстань до денної поверхні в місці встановлення деформографів становила більше ніж 15 м, що забезпечило спільно з обладнанням шлюзів порівняно добре нівелювання прямого впливу сезонних коливань температури повітря та земної поверхні на результати вимірювань деформацій масиву порід.

Але за рахунок термопружних деформацій, генерованих приповерхневими (на глибинах 0,2-5 м) шарами консолідованих порід південного схилу гори Мужіївської, все ж таки рівень сезонних варіацій напружено-деформованого стану масиву порід у зоні розташування деформографів був значний (див. нижче). Тому раніше (див. [Назаревич и др., 2007]) на записах деформацій цього пункту нам вдалося виділити і дослідити тільки виразну аномалію - провісник землетрусу 6.05.1989 р., подібну за характером та часовоамплітудними параметрами до виділеної ще раніше відповідної геоакустичної аномалії [Вербицький, Назаревич, 2005].

Водночас відомо, що роком раніше у цій самій зоні також відбувся відчутний землетрус, але на записах деформографа явної аномалії в цей час не спостерігалося.

I все ж за уважнішого розгляду на графіку деформації за 1986-1990 рр (див. нижче) можна помітити певні збурення ходу сезонної деформації у другій половині 1988 р. Але вони могли бути пов'язані з особливістю сезонної метеотемпературної хвилі, тому без детального кореляційного аналізу деформографічних та температурних даних робити якісь висновки тут не було можливим.

Для проведення такого аналізу ми залучили дані про зміни температури повітря та поверхні грунту на розташованій недалеко від пункту спостережень (на відстані 3 км (рис. 11)) метеостанції "Берегове" за 1986-1990 pp. (рис. 12, a).

3 цих даних за результатами спектрального аналізу виділено сезонну температурну хвилю i проведено іiі кореляційний аналіз 3 деформографічними даними. За результатами цього аналізу (з урахуванням трендової та сезонної складових (див. нижче)) згенеровано модельну “стаціонарну" термопружну деформацію на пунті "Мужієво" (рис. 12, б). Далі шляхом порівняння 3 фактичними деформаціями порід (рис. 13) виділено малоамплітудну (порівняно 3 сезонними термопружними деформаціями і 3 провісником Виноградівських землетрусів 1989 р.) аномалію - провісник Виноградівського землетрусу 1988 р., представлену на рис. $13, a$ ) (загальний вигляд) і рис. 13, б) (варіаційна складова).

Зазначимо, що величина виділеної аномалії $\epsilon$ порівняно малою (див. рис. 13) - відносна деформація становить $\sim 3 \times 10^{-7}$. Порівняно $з$ величиною сезонних метеотермопружних варіацій $\left(\sim 14 \times 10^{-7}\right)$ аномалія $є$ у 5 разів меншою і без детального дослідження і урахування сезонних метеотемпературних впливів виділити іiї не було можливим.

Водночас порівняно 3 варіаціями деформацій відносно згенерованої (з урахуванням трендової та сезонної складових) модельної “стаціонарної” термопружної деформації за попередні 2 роки (липень 1986 р. - червень 1988 р.), величини яких не перевищують у середньому $0,5-0,7 \times 10^{-7}$ (рис. 13, б), така аномалія є у 5-7 разів більшою, тобто виділяється досить надійно (рис. 13, б) - на рівні значно більше ніж $3 \sigma$.

Тривалість аномалії перед землетрусом становила не менше ніж 5 місяців - відхилення від “стаціонарного" ходу деформацій почалися в липні 1988 р., а сам землетрус відбувся 12 грудня 1988 р.

Аналізуючи коротко виділену аномалію порівняно $з$ аномалією землетрусів 1989 р. (рис. 13), зазначимо, що аномалія від землетрусу 1988 р. є у кілька разів менш вираженою. Це стосується як самої аномалії (відносна деформація $3 \times 10^{-7}$ порівняно $3 \sim 13 \times 10^{-7}$ ), так і зміни трендової складової геомеханічного режиму земної кори (для аномалії провісника землетрусу 1988 р. зміна тренду помітно не простежується, а для аномалії - провісника землетрусів 1989 р. наявна зміна стиску величиною $\sim 11 \times 10^{-7}$ на рік розтягом величиною $\sim 3 \times 10^{-7}$ на рік). Щоправда, епіцентральна відстань для землетрусу 1988 р. $(\Delta=31$ км $)$ у півтора раза більша, ніж для землетрусу 1989 р. ( $\Delta=23$ км). Але, з іншого боку, i магнітуда землетрусу 1988 р. $(\mathrm{M}=3,3 / \mathrm{K}=9,9)$ помітно більша, ніж для землетрусу 1989 p. (M = 2,8/K = 9,1), тобто, за енергією ці землетруси різняться майже на порядок.

Така відмінність між розглянутими деформаційними провісниковими аномаліями кореспондується з відмінністю між відображеннями цих же землетрусів у геоакустичних даних. Геоакустична аномалія - провісник землетрусів 1989 р. є дуже виразною ([Вербицький, Назаревич, 2005; Назаревич и др., 2007] та ін.). 


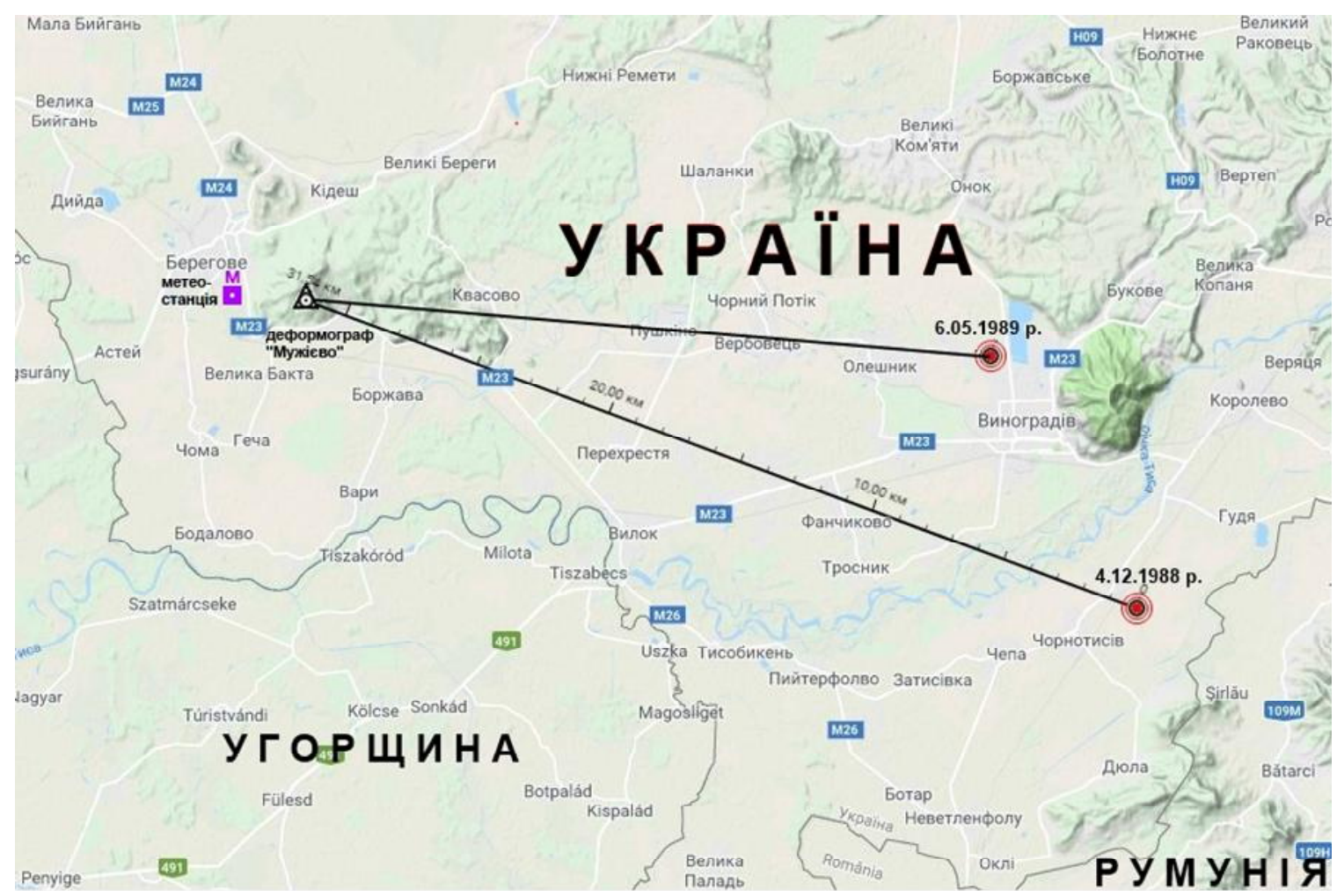

Рис. 11. Локалізація вогнищ відчутних місцевих Виноградівських землетрусів 1988-1989 pp. відносно пункту спостережень “Мужієво” (“Берегове-1”) на фрагменті карти центральної частини південної зони Закарпаття (на картооснові Google з рельєфом, показана локалізація вогнищ землетрусів (•), пункту “Мужієво” ( $\boldsymbol{\Delta}$ ) та епіцентральні відстані до вогнищ,

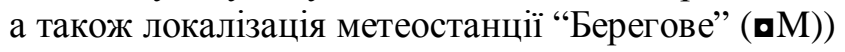

Fig. 11. Localization of the foci of the tangible local Vynogradovo earthquakes in 1988-1989 relative to the "Muzhievo" ("Beregovo-1") observations on a fragment of the map of the central part of the Transcarpathians southern zone (on the Google maps with a relief, the localizations of earthquake foci $(\bullet)$, the "Muzhievo" point $(\mathbf{\Delta})$, epicentral distances to the foci and the "Beregovo" meteorological station ( $\mathbf{0} M)$ are showing)

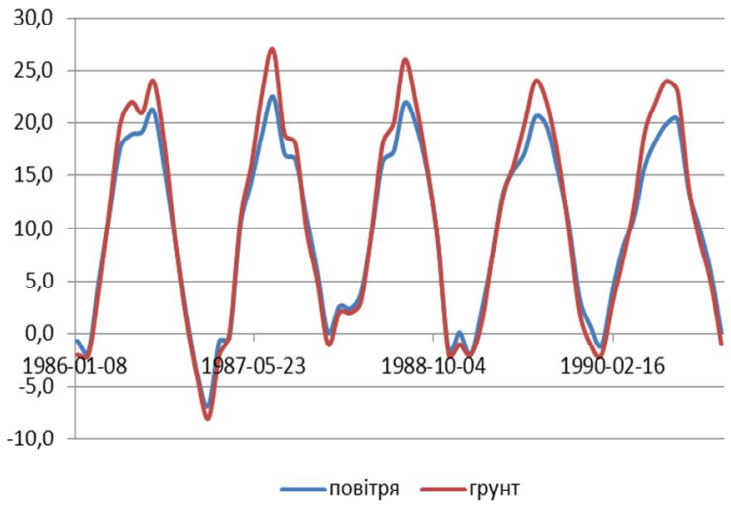

$a$

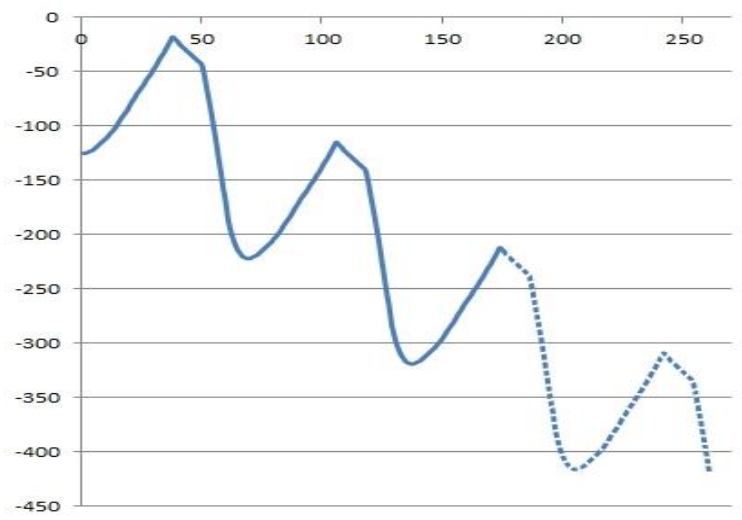

$\sigma$

Рис. 12. Середньомісячні значення температури повітря та поверхні грунту на метеостанції “Берегове” за 1986-1990pp. (а) та модельна “стаціонарна” термопружна деформація на пунті "Мужієво" (з урахуванням трендової та сезонної складових) (б)

Fig. 12. The average monthly values of temperature of the air and soil surface at the "Beregovo" meteorological station for 1986-1990 (a) and the simulated "stationary" thermoelastic deformation at the "Muzhievo" pint (taking into account the trend and seasonal components) (б) 

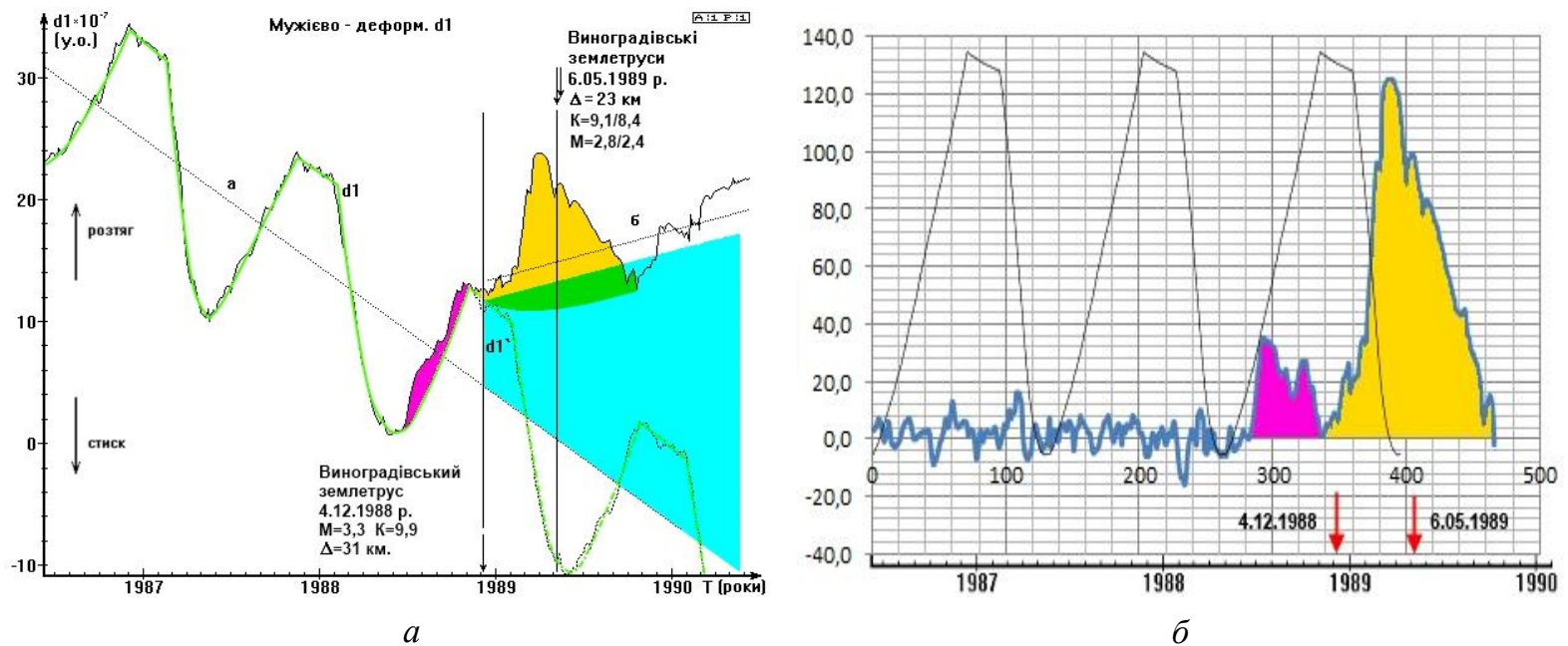

Рис. 13. Виділення (з урахуванням сезонних метеотермопружних деформацій) малоамплітудної деформаційної аномалії (відміченої рожевим) - провісника Виноградівського землетрусу 4.12.1988 р. (пояснення - в тексті): $a$ - на фоні повного часового ряду; $\sigma$ - варіаційні складові, на фоні сезонних деформаційних хвиль (шкала деформацій - в умовних одиницях). Показано також аномалія - провісник Виноградівського землетрусу 6.05.1989 р. (зазначена жовтим), яку ми виділили раніше [Назаревич и др., 2007]

Fig. 13. Selection (taking into account the seasonal meteothermal deformations) of the low-amplitude deformation anomaly (marked by pink) - the precursor of the Vynohradovo earthquake on December 4, 1988 (explanations are in the text): $a$-on the background of the full time series; $b$ - the variational components, on the background of seasonal deformation waves (scale of deformations - in the conventional units). The selected by us before [Nazarevych et al., 2007] the anomaly of the Vynogradovo earthquake on May 6, 1989 (marked by yellow) is also shown

А геоакустична аномалія-провісник землетрусу 1988 р. виразно не простежується [Вербицький, Назаревич, 2005].

Очевидно, відмінність між аномаліями - провісниками землетрусів 1988 і 1989 років спричинена, значною мірою, особливостями геомеханіки їхніх вогнищевих зон, відмінностями механізмів цих землетрусів і відмінностями будови земної кори на трасах "вогнище - пункт спостережень". Усі ці питання потребують подальшого детального і комплексного аналізу.

Щодо “провісникової” тривалості, то обидві аномалії подібні - вони почалися приблизно за 5 місяців до відповідних сейсмічних подій: перша в липні 1988 р., а сам землетрус відбувся 12 грудня 1988 р.; друга - у грудні 1988 р., а сам землетрус відбувся 6 травня 1989 р. Але постсейсмічна тривалість аномалії 1989 р. є значно більшою, також близько п'яти місяців після землетрусу (рис. 13), тоді як аномалія 1988 р. закінчилась ще перед “своїм" землетрусом. Щоправда, тут, можливо, виникло перекриття початком аномалії 1989 р. “хвоста" аномалії 1988 р., але об'єктивно встановити це не видається можливим.

\section{Наукова новизна}

Науковою новизною описаних досліджень $є$ те, що досягнуто підвищення чутливості i точності моніторингових та інших свердловинних геотер- мічних досліджень 3 використанням розробленої свердловинної геотермічної апаратури 3 кварцовим термочастотним сенсором, шляхом, зокрема, дослідження, визначення і врахування таймінгових температурних поправок (“інтервальних зміщень”) і поправок за теплову інерційність свердловинного зонда. Детально досліджено температурні профілі низки гідротермальних свердловин заходу України і встановлено особливості зміни в них температур з глибиною. За рахунок редукції 3 деформографічних даних змодельованих за результатами геотермічного моніторингу сезонних термопружних деформацій виділено малоамплітудний деформаційний провісник місцевого закарпатського землетрусу.

\section{Практична значущість}

Досягнуто підвищення глибинності геотермічних досліджень 3 використанням розробленої свердловинної геотермічної апаратури за рахунок використання кратно зниженої частоти передачі вимірюваного сигналу каротажним кабелем і вдосконалення конструкції та схемотехніки свердловинного зонда.

\section{Висновки}

Підсумовуючи викладене, можна серед найосновнішого відзначити таке: 
1. Для підвищення ефективності та оперативності термокаротажних досліджень, розширення робочого діапазону глибин та вирішуваних задач, підвищенння надійності розроблену апаратуру суттєво модифіковано, зокрема, реалізовано низку заходів з модифікації зонда: зниження робочої частоти на сигнальному кабелі, зменшення теплової інерційності зонда та збільшення робочого гідростатичного тиску, а також метрологічних характеристик вимірювальних систем. Розроблений модифікований варіант свердловинної геотермічної апаратури 3 глибинним свердловинним зондом забезпечує дослідження температурного режиму свердловин на глибинах у сотні метрів 3 розділенням по температурі на рівні $0,001{ }^{\circ} \mathrm{C}$. Це значно підвищує потенціал такої апаратури у проведенні різних практичних досліджень.

2. Отримані під час випробувань апаратури на свердловинах у Закарпатті (свердловини № 16-п на пункті “Косино” i № 838 на РГС “Тросник”) i Передкарпатті (сведловина Брюховичі-1) дані свідчать про помітно вищі температурні градієнти за глибиною у Закарпатті - у Косино і Троснику (порядку $0,05-0,07^{\circ} \mathrm{C}$ ), ніж у районі Львова (близько $0,03^{\circ} \mathrm{C}$ ).

3. За результатами досліджень у свердловині № 838 РГС “Тросник” встановлено різку (до 7 разів) зміну геотермічного градієнту з глибиною від 0,008-0,02 ${ }^{\circ} \mathrm{C} / \mathrm{M}$ на глибинах 20-100 м до 0,05$0,07{ }^{\circ} \mathrm{C} / \mathrm{м}$ на глибинах $150-500$ м. Отже, найдоцільніше тут вести моніторингові геодинамічні і сейсмопрогностичні дослідження на глибинах $200-250$ м, тобто в зоні найбільших $(0,065-$ $0,068^{\circ} \mathrm{C} / \mathrm{M}$ ) температурних градієнтів (найбільшої чутливості до змін напружено-деформованого стану масиву порід).

4. Використання розробленої методики врахування теплової інерційності зонда і введення відповідних поправок у виміряні значення температур (проілюстроване на прикладі обробки даних свердловини № 16-п Косино) дає змогу підвищити точність i/або значно прискорити швидкість термокаротажу та збільшити його детальність за глибиною зі збереженням точності та якості отримуваних даних.

5. За результатами аналізу даних геотермічних досліджень на свердловині пункту "Косино" (на глибині 50 м) за період з листопада-грудня 2010 р. до червня-липня 2011 р. зафіксовано зниження температури на $0,15^{\circ} \mathrm{C}-3 \quad 18,325$ до $18,175^{\circ} \mathrm{C}$ [Назаревич, Микита, 2012], що може бути пов'язане 3 процесами підготовки відчутного Берегівського землетрусу 10 серпня 2011 р., який відбувся за 17 км на південній схід від пункту спостережень.

6. Розроблена методика дослідження і врахування метеотемпературних впливів на геофізичні (зокрема, деформографічні) дані дає можливість ефективно враховувати (редукувати на порядок i більше) метеотермопружні деформації і за рахунок цього виділяти 3 деформографічних даних ма- лоамплітудні (на рівні у кілька разів менше амплітуд сезонних термопружних деформацій) деформаційні аномалії - провісники місцевих землетрусів. Це детально показано на прикладі виділення малоамплітудної аномалії - провісника Виноградівського землетрусу 4.12 .1988 р. Можливості виділення таких аномалій фактично у кілька разів збільшують реальну чутливість i/або зону контролю конкретного пункту деформографічних спостережень, даючи змогу виявляти деформаційні провісникові аномалії на тих самих, що й раніше, епіцентральних відстанях від значно слабших землетрусів, i на значно більших відстанях від землетрусів такої ж, як раніше, магнітуди. Це значно підвищує ефективність (враховуючи відомі [Латынина и др., 1988; Вербицький, Назаревич, 2005; Назаревич, 2011] обмеження методичного та економічного характеру) і результативність деформографічних сейсмопрогностичних та інженерно-геофізичних досліджень і моніторингу.

Узагальнюючи викладені результати досліджень, можемо констатувати, що розроблені методики геотермічних досліджень, аналізу та застосування їхніх результатів, а також створена геотермічна апаратура забезпечують ефективне вивчення різномасштабних приповерхневих та глибинних геотермічних та інших геодинамічних процесів [Крупський, 2001; Дослідження..., 2005] у Карпатському регіоні України ([Назаревич, 2008, 2011; Вербицький, Назаревич, 2005; Назаревич и др., 2007; Назаревич, Микита, 2012; Назаревич, Назаревич, 2017] та ін.).

Так, запропонована методика сейсмопрогностичних геотермічних досліджень у Закарпатті 3 використанням гідротермальних свердловин та створеної геотермічної апаратури 3 кварцовими термочастотними датчиками здатна забезпечити виявлення процесів підготовки регулярно виникаючих тут відчутних місцевих землетрусів [Дослідження..., 2005; Назаревич, Назаревич, 2013; Kalenda et al., 2013; Starostenko et al., 2013] у радіусі до кількох десятків кілометрів від пункту спостережень. Розширення мережі пунктів та вдосконалення апаратури дає змогу забезпечити проведення сейсмопрогностичного моніторингу на всій території сейсмоактивного Закарпатського прогину 3 можливістю оцінок величин змін напружено-деформованого стану масивів порід у пунктах спостережень [Назаревич, Микита, 2012].

Можливості та перспективи застосування розробленої апаратури та методик свердловинних геотермічних досліджень у нафтогазопошукових задачах також досить значні. Порівнюючи дані наших свердловинних термокаротажних досліджень (термопрофілювання свердловин) 3 результатами інших авторів ([Чекалюк и др., 1974; Kalenda et al., 2014] та ін.), бачимо (див. також у [Назаревич, Микита, 2012]) можливість та перспективність застосування розробленої апаратури 
та методик для виділення різних за своїми геотемпературними параметрами та флюїдним режимом горизонтів.

Розроблені методики, апаратура та результати досліджень можна також використати для вивчення і подальшої розробки перспективних гідротермальних енергоресурсів Закарпаття, потужні запаси яких $\epsilon$ як на великих (7-11 км) [Ковалишин, Братусь, 1984; Назаревич та ін., 2002; Kováčiková et al., 2016; Назаревич, Назаревич, 2017], так і на порівняно значно менших i доступних (до 3-5 км) глибинах.

\section{Список літератури}

Альтшуллер Г. Б. Кварцевые генераторы: справ. пособ. / Г. Б. Альтшуллер, Н. Н. Елфимов, В. Г. Шакулин. - М. : Радио и связь, 1984. $232 \mathrm{c}$.

Аннюк Ф. М. Геотермическая станция ГС-1 / Ф. М. Аннюк, В. Г. Осадчий, Р. И. Филюс, Э. Б. Чекалюк // Приборы для научных исследований и системы автоматизации в АН УССР. - К. : Наук. думка. - 1981. - С. 79-80.

Вербицький Т. 3. Деформографічні і геоакустичні дослідження у Закарпатті / Т. 3. Вербицький, А. В. Назаревич // Дослідження сучасної геодинаміки Українських Карпат / за ред. В. І. Старостенка. - К. : Наук. думка, 2005. C. 113-131.

Гогель Ж. Геотермия / Ж. Гогель. - М. : Мир, 1978. - $171 \mathrm{c}$.

Гордиенко В. В. Тепловое поле территории Украины / В. В. Гордиенко, И. В. Гордиенко, О. В. Завгородняя, О. В. Усенко. - К. : Знание Украины, 2002. - $170 \mathrm{c}$.

Гордиенко В. В. Украинские Карпаты (геофизика, глубинные процессы) / В. В. Гордиенко, И. В. Гордиенко, О.В.Завгородняя, С. Ковачикова, И. М. Логвинов, В. М. Тарасов, О. В. Усенко. - К. : Логос, 2011. - 129 с.

Добровольский И. П. Теория подготовки тектонического землетрясения / И. П. Добровольский. - М. : ИФЗ РАН, 1991. - 219 с.

Дослідження сучасної геодинаміки Українських Карпат / під ред. В. І. Старостенка. - К. : Наук. думка, 2005. - 254 с.

Ковалишин 3. И. Флюидный режим гидротермальных процессов Закарпатья / 3. И. Ковалишин, М. Д. Братусь. - К. : Наук. думка, 1984. - 86 с.

Кончаловский В. Ю. Цифровые измерительные устройства / В. Ю. Кончаловский. - М. : Энергоатомиздат, 1985. - 304 с.

Крупський Ю. 3. Геодинамічні умови формування і нафтогазоносність Карпатського та ВолиноПодільського регіонів України / Ю. 3. Крупський. - К. : УкрДГРІ, 2001. - 144 с.

Кутас Р. И. Поле тепловых потоков и геотермическая модель земной коры / Р. И. Кутас. - К. : Наук. думка, 1978. - 140 с.

Кутас Р. И. Тепловое поле Украины / Р. И. Кутас, В. В. Гордиенко. - К. : Наук. думка, 1971. - 112 с.
Кутас Р. І. Геодинамічні процеси і тепловий стан літосфери Карпатського регіону - В кн.: Дослідження сучасної геодинаміки Українських Карпат / Р. І. Кутас; під ред. В. І. Старостенка. - К. : Наук. думка, 2005. - С. 132-139.

Латинина Л. А. Результаты деформационных измерений в районе Берегово / Л. А. Латинина, О. И. Юркевич, И. М. Байсарович // Геофиз. журн. - 1992. - Т. 14, № 2. - С. 63-67.

Латынина Л. А. Методические рекомендации по исследованию деформационных предвестников землетрясений / Л. А. Латынина, Н. А. Жаринов, М. В. Крамер, И. В. Савин, И. А. Широков. - М. : ИФЗ АН СССР, 1988. $81 \mathrm{c}$.

Малов В. В. Пьезорезонансные датчики / В. В. Малов. - М. : Энергия, 1978. - 248 с.

Назаревич А. Моніторинг сезонного температурного режиму приповерхневих шарів порід та грунтів у Західному регіоні України / А. Назаревич, В. Осадчий, Л. Назаревич, М. Баштевич, В. Смичок, О. Бурнаєв, Р. Назаревич // Матер. Міжнар. наук.-техн. конф. молодих вчених “GEOTERRACE-2016", 15-17 грудня 2016, Львів, Україна. - Львів. - 2016 (CD).

Назаревич А. В. Автоматический цифровой геоакустический комплекс / А. В. Назаревич // Сейсмопрогностические исследования на территории УССР. - К. : Наук. думка. - 1988. C. $116-123$.

Назаревич А. В. Деформаційні провісники відчутних Виноградівських землетрусів Закарпаття: аналіз деформаційних процесів та оцінка величин деформацій у вогнищі / А. В. Назаревич // Вісник КНУ ім. Т. Шевченка. Геологія. 2008. - № 45. - С. 23-30.

Назаревич А. В. Методико-апаратурні проблеми моніторингових геофізичних досліджень та шляхи їх розв'язання (на прикладі геофізичного сейсмопрогностичного моніторингу в Закарпатті) / А. В. Назаревич // Вісник КНУ ім. Тараса Шевченка. Геологія. - 2011. № 55. - С. 57-60.

Назаревич А. В. О перспективах скважинных геотермических исследований высокого разрешения в поисках нефтегазовых залежей / А. В. Назаревич, Л. Е. Назаревич, Н. В. Баштевич // 5-я Междунар. науч.-практ. конф. “Современные сейсмические и другие геолого-геофизические методы при поисках месторождений нефти и газа в условиях сложнопостроенных структур (Сейсмо-2014)". 7-13 сентября 2014 г. Одесса (Украина) : Сб. матер. - Одесca. -2016 (CD).

Назаревич А. В. Геодинаміка сейсмоактивних районів Закарпаття за комплексом геофізичних даних / А. В. Назаревич, 3. І. Ковалишин, Л. Є. Назаревич // Вісник КНУ ім. Т. Шевченка. Геологія. - 2002. - № 23-24. - С. 38-43. 
Назаревич А. В. Геоакустические и деформационные предвестники ощутимых закарпатских землетрясений / А. В. Назаревич, Л. А. Латынина, Л. Е. Назаревич // Сб. матер. междунар. конф. "Уроки и следствия сильных землетрясений”. Ялта, 25-28 сентября 2007 г., Крым, Украина. - Симферополь. - 2007. - С. 144-146.

Назаревич А. В. Геотермічний метод у сейсмопрогностичних дослідженнях у Закарпатті / А. В. Назаревич, А. Ю. Микита // Вісник КНУ ім. Тараса Шевченка. Геологія. - 2012. - № 58. - С. 16-19.

Назаревич А. В. Метеотемпературні поля в масивах порід (як фактор впливу на результати деформографічних спостережень на РГС "Берегове” у Закарпатті) / А. В. Назаревич, А. Ю. Микита // Теоретичні та прикладні аспекти геоінформатики. - К. - 2010. - С. 286-299.

Назаревич А. В. Геодинаміка, тектоніка та сейсмічність Карпатського регіону України / А. В. Назаревич, Л. Є. Назаревич // Геодинаміка. - 2013. - № 2 (15) - С. 247-249.

Назаревич А. В. Масштабно-енергетичні кореляційні співвідношення для вогнищ землетрусів Закарпаття: деякі наслідки та енергетична верифікація / А. В. Назаревич, Л. С. Назаревич // Теоретичні та прикладні аспекти геоінформатики. - К. - 2009. - С. 279-298.

Назаревич А. В. Про перспективні гідротермальні ресурси Карпатського регіону / А. В. Назаревич, Л. Є. Назаревич // 16-та Міжнар. наук.-практ. конф. "Ресурси природних вод Карпатського регіону (проблеми охорони та раціонального використання)" : Зб. наук. ст. 25-26 травня 2017 р., м. Львів. - Львів. 2017. - C. $170-172$.

Осадчий В. Г. Характеристики температурного режиму приповерхневих шарів гірських порід за даними досліджень на геофізичній станції “Лисовичі" (Передкарпаття) / В. Г. Осадчий, А. В. Назаревич, Л. Є. Назаревич // Геодинаміка. - 2008. - № 1(7). - С. 96-102.

Патент UA 111484, Україна, МПК G01K 1/08, $\mathrm{G01K}$ 7/32. Свердловинний термометричний перетворювач / Д. В. Малицький, А. В. Назаревич, О. О. Муйла, А. Ю. Микита, І. Б. Бутитер
(Україна). Заявник та патентовласник - Карпатське відділення інституту геофізики ім. С. І. Субботіна НАН України. - № а 2013 10786; заявл. 09.09.2013; опубл. 10.05.2016, Бюл. № 9. - 2 с.

Скакальська Л. В., Назаревич А. В., Струк С. С. Алгоритми та програми обробки каротажних даних у прогнозуванні нафтогазоносності порід / Л. В. Скакальська, А. В. Назаревич, Є. С. Струк // Вісник Нац. ун-ту “Львівська політехніка" “Комп”ютерні науки та інформаційні технологіï. - 2017. - № 864. C. 210-221.

Фролов Н. М. Температурный режим гелиотермозоны / Н. М. Фролов. - М. : Недра, 1966. $156 \mathrm{c}$.

Чекалюк Э. Б. Термодинамика нефтяного пласта / Э. Б. Чекалюк. - М. : Недра, 1965. - 240 с.

Чекалюк Э. Б. Полевая геотермическая съемка / Э. Б. Чекалюк, И. М. Федорцов, В. Г. Осадчий. - К. : Наук. думка, 1974. - 103 с.

Hvožd'ara, M., Brimich, L., Skalský, L. (1988): Thermoelastic deformations due to annual temperature variation at the tidal station in Vyhne. Studia Geophysica et Geodaetica, Vol. 32, No. 2, 129-135.

Kalenda P., Ozounov D., Bobrovskij V., Neumann L., Boborykina O., Nazarevych A., Šebela S., Kvetko J., Shen W-B. Multi-parameter and multi-sensors approach to the earthquake prediction // EGU 2013, Vienna, 7-12 April, 2013. - EGU2013-7592.

Kalenda P., Wandrol I., Procházka V., Neumann L. Exogenous mechanism of global tectonics // XIIIth International Conference on Geoinformatics - Theoretical and Applied Aspects. 1215 May 2014, Kiev, Ukraine. - Kiev, 2014 (CD).

Kováčiková S., Logvinov I., Nazarevych A., Nazarevych L., Pek J., Tarasov V., Kalenda P. Seismic activity and deep conductivity structure of the Eastern Carpathians. Stud. Geophys. Geod., 2016, 60, P. 1-17, DOI: 10.1007/s11200-014-0942-y.

Starostenko V., Janik T., Kolomiyets K. et al. Seismic velocity model of the crust and upper mantle along profile PANCAKE across the Carpathians between the Pannonian Basin and the East European Craton. Tectonophysics, 2013, 608, 1049-1072.

\section{А. НАЗАРЕВИЧ}

Карпатское отделение Института геофизики им. С. И. Субботина НАН Украины, 79060, г. Львов, ул. Научная, 3б, тел. +38(032)2648563, эл. почта nazarevych-a@ cb-igph.lviv.ua

\section{К ПРОБЛЕМЕ ПОВЫШЕНИЯ ГЛУБИННОСТИ, ЧУВСТВИТЕЛЬНОСТИ И ТОЧНОСТИ МОНИТОРИНГОВЫХ И НЕФТЕГАЗОПОИСКОВЫХ СКВАЖИННЫХ ГЕОТЕРМИЧЕСКИХ ИССЛЕДОВАНИЙ}

Цель. Целью работы является представить наработанные нами важные методико-аппаратурные разработки, направленные на повышение глубинности, чувствительности и точности мониторинговых и нефтегазопоисковых скважинных геотермических исследований. Методика. Методика включает анализ ряда методико-аппаратурных факторов, влияющих на глубинность, чувствительность и точность скважинных геотермических исследований с использованием разработанной скважинной аппаратуры с кварцевым термочастотным сенсором и соответствующие методико-аппаратурные разработки для 
повышения этой глубинности, чувствительности и точности. Результаты. Анализ результатов, проведенных нами ранее скважинных геотермических исследований с использованием разработанной скважинной аппаратуры с кварцевым термочастотним сенсором, показал, что наряду с высокой общей чувствительностью и точностью разработанной аппаратуры имеют место ограничения ее глубинности из-за недостаточной герметичности зонда при работе в скважинах на больших глубинах при действующих там высоких гидростатических давлениях жидкости, заполняющей скважину. Поэтому, в первую очередь, усовершенствована конструкция зонда с целью обеспечения его надежной работы на больших глубинах. Также имеется ограничение глубинности (в частности, допустимой длины каротажного кабеля) скважинных исследований при “прямой” передаче результатов измерений этим кабелем из-за большого затухания сигнала на рабочей частоте высокочастотного кварцевого термочувствительного сенсора. Поэтому, рабочая частота канала передачи результатов кратно снижена путем использования цифрового делителя частоты. Также наблюдается влияние на эти результаты ряда методико-аппаратурных факторов, ухудшающих их качество, особенно при отслеживании быстрых изменений температуры в скважине во время еe термопрофилирования (высокоскоростного термокаротажа) или режимного мониторинга. Это, в частности, тепловая инерционность скважинного зонда. Для нейтрализации влияния этой инерционности проведены ее исследования и предложен способ редукции ее влияния путем введения соответствующих таймингозависимых температурных поправок. Проведено термопрофилирование ряда гидротермальных скважин запада Украины и полученные результаты откорректированы с учетом перечисленных поправок. Разработана методика выявления и учета метеотемпературных воздействий на результаты сейсмопрогностических мониторинговых исследований по данным геотермического мониторинга массивов пород. Она представлена на примере выделения на фоне сезонных термоупругих деформаций малоамплитудного деформационного предвестника местного закарпатского землетрясения. Научная новизна. Достигнуто повышение чувствительности и точности мониторинговых и нефтегазопоисковых скважинных геотермических исследований с использованием разработанной скважинной геотермической аппаратуры с кварцевым термочастотным сенсором, путем, в частности, исследования, определение и учета тайминговых температурных поправок (“интервальных смещений”) и поправок за тепловую инерционность скважинного зонда. Подробно исследованы температурные профили ряда гидротермальных скважин запада Украины и установлены особенности изменения в них температур с глубиной. За счет редукции из деформографических данных смоделированных по результатам геотермического мониторинга сезонных термоупругих деформаций пород выделен малоамплитудный деформационный предвестник местного закарпатского землетрясения. Практическая значимость. Достигнуто повышение глубинности геотермических исследований с использованием разработанной скважинной геотермической аппаратуры за счет использования кратно пониженной частоты передачи измеряемого сигнала каротажным кабелем и усовершенствования конструкции и схемотехники скважинного зонда.

Ключевые слова: термокаротаж; скважинный зонд; кварцевый термочастотный сенсор; тепловая инерционность; температурные поправки; температурный профиль скважины; динамические температурные вариации; предвестники землетрясений.

\section{A. NAZAREVYCH}

Carpathian Branch of Subbotin Name Institute of Geophysics of NAS of Ukraine, 3-b, Naukova Str., 79060, Lviv, Ukraine, tel. +38(032)2648563, e-mail nazarevych-a@cb-igph.lviv.ua

\section{TO THE PROBLEM OF IMPROVING THE DEPTH, SENSITIVITY, AND ACCURACY OF MONITORING AND OIL AND GAS SEARCHING BOREHOLE GEOTHERMAL RESEARCHES}

Purpose. The purpose of the work is to present important methodological and instrumental solutions to improve the depth, sensitivity, and accuracy of monitoring and oil and gas searching borehole geothermal research. Methodology. The technique includes the analysis of a number of methodological and instrumental factors, which affect the depth, sensitivity, and accuracy of borehole geothermal research using the developed downhole equipment with a quartz thermo-frequency sensor and appropriate methodological and instrumental developments to increase this depth, sensitivity, and accuracy. Results. An analysis of the results of our previous borehole geothermal studies using the developed downhole equipment with a quartz thermo-frequency sensor showed that along with the high overall sensitivity and accuracy of the developed equipment, there are limitations of its depth due to insufficient hermeticity of the well $\log$ sonde when it is working in wells on the great depths at operating there high hydrostatic pressures of fluid filling the well. Therefore, we first improve the construction of the well $\log$ sonde for the purpose of ensuring its reliable operation at great depths. There is also a depth limitation (in particular, the allowable length of the logging cable) of borehole studies with the "direct" transfer of measurements results by this cable due to the large attenuation of the signal of the high operating frequency of the quartz thermosensitive sensor. Therefore, the operating frequency of the transmission channel 
(on the logging cable) was significantly reduced by a digital divider. Also we can see the influences of a number of methodological and instrumental factors on the quality of these results, especially when we follow up the rapid changes in the temperature in the well during its thermal profiling (high-speed thermal logging) or regime monitoring. This, in particular, is the thermal inertia of the well log sonde. To neutralize the effect of this inertia, studies were carried out and a method for reducing its influence was proposed by introducing appropriate timings-dependent temperature corrections. Thermal profiling of a number of hydrothermal wells in the west of Ukraine was carried out and the results were corrected taking into account the listed corrections. The method of detection, taking into account the meteorological influences on seismoprognostic monitoring, was developed based on geothermal monitoring of rock massifs. It presented the seasonal thermoelastic deformations with lowamplitude deformation, a precursor to the local Transcarpathian earthquake. Originality. An increase of sensitivity and accuracy was reached using the developed geothermal well equipment with a quartz thermofrequency sensor, in particular, by studying, determining, and taking into account the timing`s temperature corrections ("interval shifts/delays") and corrections for the thermal inertia of the well log sonde. The temperature profiles of a number of hydrothermal wells in the west of Ukraine have been studied in detail, and the features of their temperature changes with depth, have been established. Due to the reduction from the extensometer's data the seasonal thermoelastic deformations of rocks, simulated by the results of geothermal monitoring, a low-amplitude deformation precursor of the local Transcarpathian earthquake was selected. Practical significance. An increase of the depth of geothermal studies using the developed geothermal well equipment has been achieved due to the use of a significantly reduced frequency of transmission of the measured signal on the logging cable and the improvement of the construction and circuitry of the well log sonde.

Key words: thermal logging; well log sonde; quartz thermo-frequency sensor; thermal inertia; temperature corrections; temperature profile of the well; dynamic temperature variations; precursors of earthquakes.

\section{REFERENCES}

Altshulle,r G. B., Elfimov, N. N., Shakulin, V. G. (1984). Quartz oscillators: a reference handbook, Moscow: "Radio and Communication" Publ. (in Russian).

Annyuk, F. M., Osadchiy, V. G., Filyus, R. I., \& Chekalyuk, E. B. (1981). Geothermal station GS-1, Instruments for scientific researches and systems of automation in the AN USSR, Kyiv: Naukova dumka, 79-80 (in Russian).

Verbyts'kyy, T. Z., Nazarevych, A. V. (2005). Extensometric and geoacoustic researches in Transcarpathians. Studies of modern geodynamics of Ukrainian Carpathians. Ed. V. I. Starostenko, Kyiv: Naukova dumka, 113-131 (in Ukrainian).

Gogel, G. (1978). Geothermia, Moscow: Mir (in Russian).

Gordienko, V. V., Gordienko, I. V, Zavgorodnyaya, O. V., \& Usenko, O. V. (2002). Thermal field of the territory of Ukraine, Kyiv:, Znanie Ukrainy (in Russian).

Gordienko, V. V., Gordienko, I. V., Zavgorodnjaja, O. V., Kovachikova, S., Logvinov, I. M., Tarasov, V. M., Usenko, O. V. (2011). Ukrainian Carpathians (geophysics, deep processes), Kyiv: Logos (in Russian).

Dobrovol'skiy, I. P. (1991). The theory of preparation of a tectonic earthquake. Moscow: The Schmidt Institute of Physics of the Earth of the Russian Academy of Sciences (IPE RAS) (in Russian).

Studies of modern geodynamics of Ukrainian Carpathians. Ed. V. I. Starostenko, Kyiv: Naukova dumka (in Ukrainian).

Kovalishin, Z. I, Bratus', M. D. (1984). Fluid regime of hydrothermal processes in Transcarpathians. Kyiv: Nauk. dumka (in Russian).

Konchalovskiy, V. Yu. (1985). Digital measuring devices, Moscow: Energoatomizdat (in Russian).

Krups'kyy, Yu. Z. (2001). Geodynamic conditions of formation and oil and gas content in the Carpathian and Volyno-Podillya regions of Ukraine, Kyiv, Publ. of Ukr DGRI (in Ukrainian).

Kutas, R. I. (1978). Thermal flow field and geothermal model of the Earth's crust. Kyiv: Naukova dumka (in Russian).

Kutas, R. I., Gordienko, V. V. (1971). Thermal field of Ukraine. Kyiv: Nauk. Dumka (in Russian).

Kutas, R. I. (2005). Geodynamic processes and thermal state of the lithosphere of the Carpathian region. Studies of modern geodynamics of Ukrainian Carpathians. Ed. V. I. Starostenko, Kyiv, Naukova dumka, (132-139) (in Ukrainian).

Latynina, L. A., Jurkevich, O. I., Bajsarovich, I. M. (1992). Results of deformation measurements in Beregovo area, Geophys. journal, 14(2), 63-67 (in Russian).

Latynina, L. A., Zharinov, N. A., Kramer, M. V., Savin, I. V., Shirokov, I. A. (1988). Methodical recommendations for studies of deformation precursors of earthquakes, Moscow, IFZ AS USSR (in Russian).

Malov, V. V. (1978). Piezoresonance sensors, Moscow, Energiya (in Russian).

Nazarevych, A, Osadchyy, V., Nazarevych, L., Bashtevych, M., Smychok, V., Burnaiev, O., Nazarevych, R. (2016). Monitoring of seasonal temperature regime of near-surface layers of rocks and soils in the western region of Ukraine. In Proceedings of the International scientific and technical conference of young scientists “GEOTERRACE-2016”, December 15-17, 2016, Lviv, Ukraine, Lviv, (CD) (in Ukrainian).

Nazarevych, A. V. (1988). Automatic digital geoacoustic complex. In Seismoprognostic researches in the territory of the USSR. (pp. 116-123). Kyiv: Naukova dumka" (in Russian). 
Nazarevych, A. V. (2008). Deformation precursors of tangible Vynogradiv earthquakes in Transcarpathians: analysis of deformation processes and estimation of deformation in the course. Visnyk of Taras Shevchenko National University of Kyiv, Geology. (45), 23-30 (in Ukrainian).

Nazarevych, A. V. (2011). Methodological-apparatus problems of monitoring geophysical researches and ways of their solution (on an example of geophysical seismoprognostic monitoring in Transcarpathians). [Visnyk of Taras Shevchenko National University of Kyiv, Geology, no. (55), 57-60 (in Ukrainian).

Nazarevych, A. V., Nazarevych, L. E., \& Bashtevych, N. B. (2016). On the prospects of high-resolution geothermal exploration in the search for oil and gas deposits. 5th International Scientific and Practical Conference "Modern Seismic and Other Geological and Geophysical Methods in the Search for Oil and Gas Deposits in Complex Structures" (Seismo-2014), 7-13 September 2014, Odessa (Ukraine). Proceedings], Odessa, $2016(C D)$.

Nazarevych, A. V., Kovalyshyn, Z. I., \& Nazarevych, L. Y. (2002). Geodynamics of seismically active areas of Transcarpathians by complex of geophysical data. Bulletin of Taras Shevchenko Name Kyiv National University, Geology, (23-24), 38-43 (in Ukrainian).

Nazarevych, A. V., Latynina, L. A., \& Nazarevych, L. Y. (2007). Geoacoustic and deformation precursors of tangible Transcarpathians earthquakes. Proceedings of the International conference "Lessons and consequences of strong earthquakes" Yalta, 25-28 September 2007, Crimea, Ukraine, Simferopol. 144-146 (in Russian).

Nazarevych, A. V., \& Mykyta, A. Y. (2012). Geothermal method in seismoprognostic researches in Transcarpathians. Visnyk of Taras Shevchenko National University of Kyiv, Geology. (58).16-19 (in Ukrainian).

Nazarevych, A. V., \& Mykyta, A. Y. (2010). Meteo-temperature fields in rock massifs (as a factor of influence on the results of extensometric observations in the RGS "Beregovo" in Transcarpathians). Theoretical and applied aspects of geoinformatics. 286-299 (in Ukrainian).

Nazarevych, A. V., \& Nazarevych, L. Y. (2013). Geodynamics, tectonics and seismicity of Carpathian region of Ukraine. Geodynamics. (2(15)), 247-249 (in Ukrainian).

Nazarevych, A. V., \& Nazarevych, L. Y. (2009). Scale-energy correlation values for foci of Transcarpathian earthquakes: some consequences and energy verification. Theoretical and applied aspects of geoinformatics, Kyiv. 279-298 (in Ukrainian).

Nazarevych, A. V., \& Nazarevych, L. Y. (2017). On the promising hydrothermal resources of the Carpathian region. 16th International Scientific and Practical Conference "Resources of the natural waters of the Carpathian region (problems of protection and rational use)". Collection of scientific articles. May 25-26, 2017, Lviv. 170-172 (in Ukrainian).

Osadchyy, V. G., Nazarevych, A. V., \& Nazarevych, L. Y. (2008). Characteristics of temperature regime of rocks near surface layers by data of researches in the geophysical station "Lysovychi" (Precarpathians). Geodynamics, (1(7)), 96-102 (in Ukrainian).

Patent UA 111484, Ukraine, MPK G01K 1/08, G01K 7/32. Sverdlovynnyi termometrychnyi peretvoriuvach [Well thermometric converter] Malytskyy D. V., Nazarevych A. V., Muila O. O., Mykyta A. Yu., Butyter I. B. (Ukraine). Zaiavnyk ta patentovlasnyk: Karpatske viddilennia instytutu heofizyky im. S.I. Subbotina NAN Ukrainy [Applicant and patent holder: Carpathian Branch of S. I. Subbotin name Institute of Geophysics of NAS of Ukraine], № a 2013 10786; zaiavl. [declared] 09.09.2013; opubl. [published] 10.05.2016, Bul. No. 9, 2 p.

Skakalska, L. V., Nazarevych, A. V., \& Struk, Y. S. (2017). Algorithms and programs for logging data processing in prediction of oil and gas bearing rocks in boreholes logs. Bulletin of the National University "Lviv Polytechnic" “Computer Sciences and Information Technologies", (864), 210-221 (in Ukrainian).

Frolov, N. M. (1966). Temperature regime of the geliohermal zone. Moscow: Nedra (in Russian).

Chekalyuk, E. B. (1965). Thermodynamics of oil reservoir. Moscow: Nedra (in Russian).

Chekalyuk, E. B., Fedortsov, I. M., \& Osadchyy, V. G. (1974). Field geothermal survey. Kyiv: Naukova dumka (in Russian).

Hvoždara, M., Brimich, L., \& Skalský, L. (1988). Thermo-elastic deformations due to the annual temperature variation at the tidal station in Vyhne. Studia Geophysica et Geodaetica, 32(2), 129-135.

Kalenda P., Ozounov D., Bobrovskij V., Neumann L., Boborykina O., Nazarevych A., Šebela S., Kvetko J., Shen W-B. Multi-parameter and multi-sensors approach to the earthquake prediction. EGU 2013, Vienna, 7-12 April, 2013. EGU2013-7592.

Kalenda, P., Wandrol, I., Procházka, V., \& Neumann, L. (2014). Exogenous mechanism of global tectonics. In XIIIth International Conference on Geoinformatics. Theoretical and Applied Aspects. 12-15 May 2014, Kyiv (CD).

Kováčiková, S., Logvinov, I., Nazarevych, A., Nazarevych, L., Pek, J., Tarasov, V., \& Kalenda, P. (2016). Seismic activity and deep conductivity structure of the Eastern Carpathians. Studia Geophysica et Geodaetica, 60(2), 280-296, DOI: 10.1007/s11200-014-0942-y

Starostenko, V., Janik, T., Kolomiyets, K., Czuba, W., Środa, P., Grad, M., . . . Tolkunov, A. (2013). Seismic velocity model of the crust and upper mantle along profile PANCAKE across the Carpathians between the Pannonian Basin and the East European Craton. Tectonophysics, 608, 1049-1072. doi:10.1016/j.tecto.2013.07.008

Надійшла 26.04.2018 